\title{
AZ AFRIKAI LANTOK TÖRTÉNETE ÉS TÍPUSAI
}

BRAUER-BENKE JÓZSEF

A történeti néprajz komparatív vizsgálati módszerének alkalmazásával a hangszertörténeti áttekintések arra engednek következtetni, hogy az ókori Egyiptom hasonló szerepet játszott az afrikai hangszerek történetiségét illetően, mint amilyet az ókori görög és római kultúrák gyakoroltak az európai hangszerkultúrára. Emellett az észak-afrikai régióban az ókori görög és római hangszerkultúra hatásai is erősen éreztették a hatásukat. A szubszaharai Afrika területén, a dél-afrikai régió kivételével, ha nem is mindenhol egyenlö mértékben, de szinte mindenhol megtalálhatóak az ókori egyiptomi kultúrából származó hangszerek történeti leszármazottjai, amelyek az iparosodás hiánya miatt, egészen a 20 . századig, némely esetben szinte változatlan formában maradtak fenn. Ez természetesen adott kultúra tekintetében nem jelent évezredes hagyományokat, mert az ominózus hangszertípus többszörös átvétel útján lehet, hogy csak néhány generációval azelött jelent meg a térségben. Mivel Európától eltérően a szubszaharai Afrika nagy részén a gyári hangszerek a legutóbbi időkig nem tudtak elterjedni, a térség hagyományos társadalmaiban a környezet adta anyagok használatával, egy az európai hagyományos kultúráknál jóval lassabban változó, archaikus tárgyi kultúra maradt fenn.

Azonban egy idegen kultúra behatolása egy másik kultúrába vagy akár több évszázados együttélés sem feltétlenül eredményezi a hangszerek átvételét. Példának okért a duda nem terjedt el szubszaharai Afrikában, holott Észak-Afrikában a berberek és az arabok évszázadok óta használnak dudákat (Brauer-Benke 2007: 61). Ezzel szemben a Közép-Afrika déli területén kialakult lamellofon hangszertípus a szubszaharai Afrika területén szinte mindenhol elterjedt, de Észak-Afrikában nem adatolható a jelenléte (Brauer-Benke 2018:58). A jelenségre a néprajzi kartográfia szerint az ad magyarázatot, hogy adott kultúrában az innovációk befogadását sokféle egyéni, pszichikai feltétel könnyíti, vagy éppen nehezíti (Barabás 1963: 122). A hangszertörténeti kutatásoknál mindenképpen figyelembe kell venni, hogy az öntudat a befogadás számottevő tényezőjeként hat és ezen belül különösen a faluközösségi, a nemzetiségi, törzsi vagy vallási csoportöntudat bír nagy jelentőséggel. Szintén fontos szempontok, a különbözö társadalmi osztályok, ezen belül a rétegek egymáshoz való viszonya, az illető hely megközelíthetősége és indusztriáltságának a mértéke, illetve más helyiségektől való távolsága (Szolnoky 1954: 65-66). Ezért összességében az interetnikus kapcsolatok útján kialakuló hangszerelterjedések fel- 
tárásához mindenképpen egy átfogó vizsgálat szükséges, amely a befogadás összes lehetséges tényezőjét áttekinti. Ennek eklatáns példája lehet az afrikai lírák és lantok elterjedése közötti különbség, mert annak ellenére, hogy mindkét hangszertípus az ókori Egyiptomból kiindulva terjedt el a szubszaharai Afrika területein, a lantok jellemzően Nyugat-Afrikában, míg a lírák jellemzően Északkelet és Kelet-Afrikában terjedtek el (Brauer-Benke 2015: 43-49).

Az eltérő történeti hátterük miatt, a lanttípusú hangszerek között megkülönböztethetünk rövid és hosszú nyakú lantokat (Sachs 1940:251). Rövid nyakú lantok esetében a hangszertest hosszabb, míg hosszúnyakú lantok esetében a hangszertest rövidebb, mint a nyak. Habár már az ókori Egyiptomban is használtak hosszúnyakú lantokat a hangszertípus legkorábbi ábrázolása Mezopotámiából, az Akkád-időszakból (Kr.e.2350-2170) származó hengerpecsétekről ismert (Rashid 1984: 62). (1. kép) Az óbabiloni időszakból (Kr.e.1950-1530) származó terrakotta ábrázolásokon már az is kivehető hogy a mezopotámiai hosszúnyakú lantoknak kerekded a hangszertestük (Rashid 1984: 92). Egy Esnunna (ma a kelet-iraki Tell Aszmar 'Vörös domb') városából a Kr.e. 18. századi kasszita időszakból fennmaradt terrakottán már az is kivehető, hogy a hosszúnyakú lant hangszerteste enyhén ovális. (2. kép) Hasonló enyhén ovális és mint az ásatások során előkerült hangszereken látható, teknőspáncélból készített rezonátortestủ hosszúnyakú lantok bukkantak fel először az ókori Egyiptomban a XVIII. dinasztia időszakában (Kr.e.1550-1292) valószínűleg az ekkor megjelenő Resef alvilági istenség (a járványok ura) kultuszával együtt (Hickmann 1961: 29). A teknőspáncél hangszertestü típusokkal egyidőben egy hosszúkás hangszertestü hosszúnyakú lanttípus is feltűnik és mindkét típus jellemzője, hogy a hangszernyak a hangszertestet fedő membránon van átfüzve (Hickmann 1961: 130-131). (3. kép)

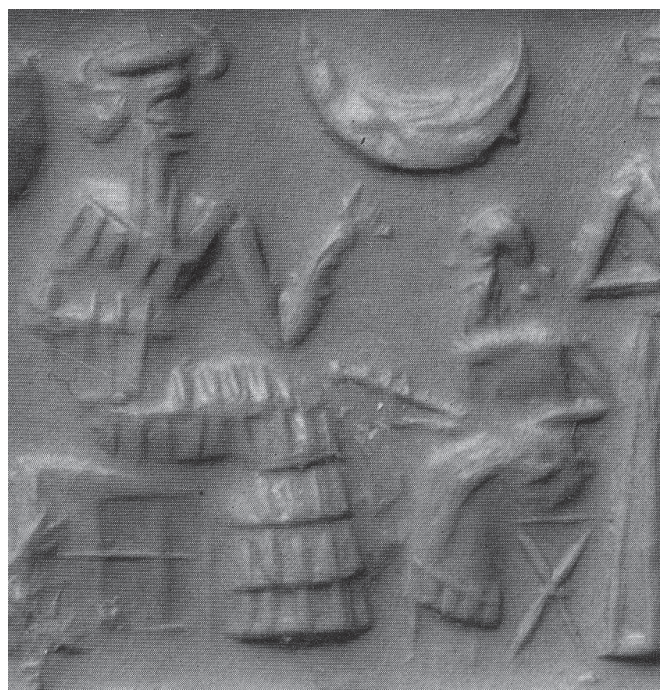

^1. kép Akkád hosszúnyakú lant Kr.e.2350-2170 (Rashid 1984 nyomán) 


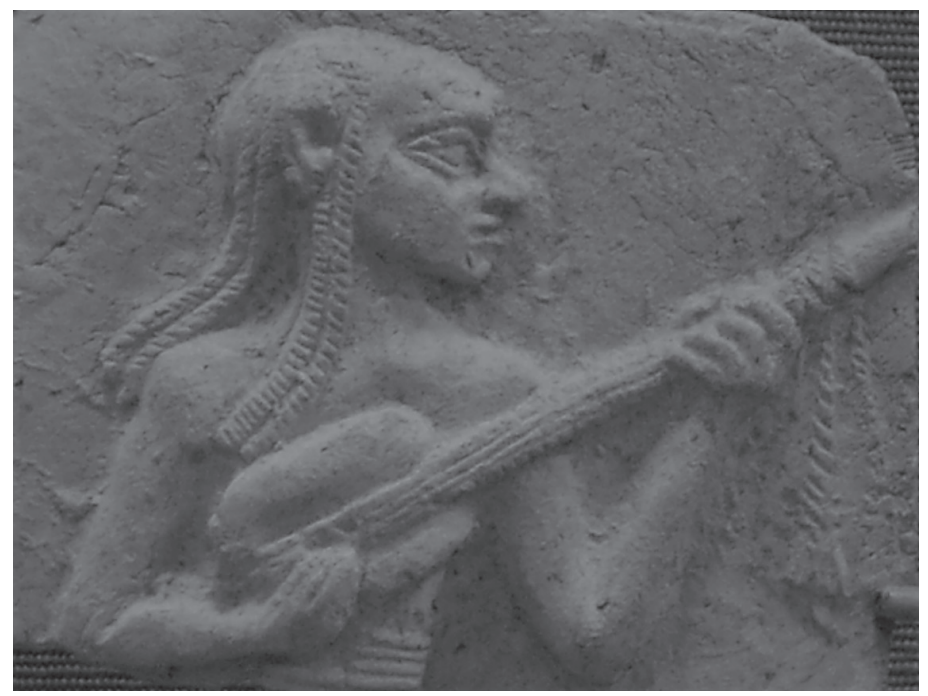

^2. kép Kasszita hosszúnyakú lant Kr.e. 14. század (Rashid 1984 nyomán)

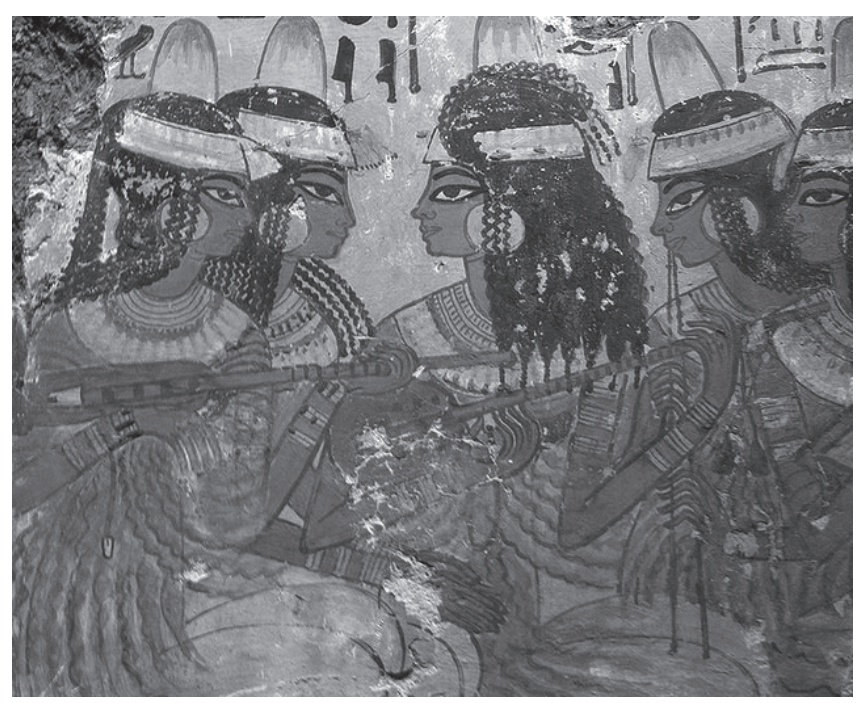

\3. kép Egyiptomi hosszúnyakú lantok a 18. dinasztia idöszakából Kr.e. 1350 (Hickmann 1961 nyomán) 
Ugyanez a megoldás maradt fenn a főleg Észak és Nyugat-Afrikában használt egyszerü felépítésü, hosszúnyakú lantokon (Collaer-Elsner 1983: 179). Az ókori egyiptomi hosszúnyakú lanton a három bélhúrt a vászonbütykök köré feszesen tekert zsinórokkal lehetett hangolni. Az eredeti ókori egyiptomi ovális hangszertest a hangerő növelése céljából Észak-Afrikában négyszögletes hangszertestü típussá fejlödött, de emellett az eredeti ovális formájú hangszertest is fennmaradt. (4. kép) A hangszertípus évezredes jelenlétének köszönhetően Észak- és Nyugat-Afrika nagyrészén elterjedt és a felépítésében kialakult kisebb különbségek, eltérő anyagok és elnevezések ellenére, egymással rokonítható hangszertípusról van szó.

Egyelöre vita tárgyát képezi, hogy az ókori egyiptomi lanttípusok Észak-Afrika vagy Szudán irányába terjedhettek tovább. Az egyik felvetés szerint az ókori

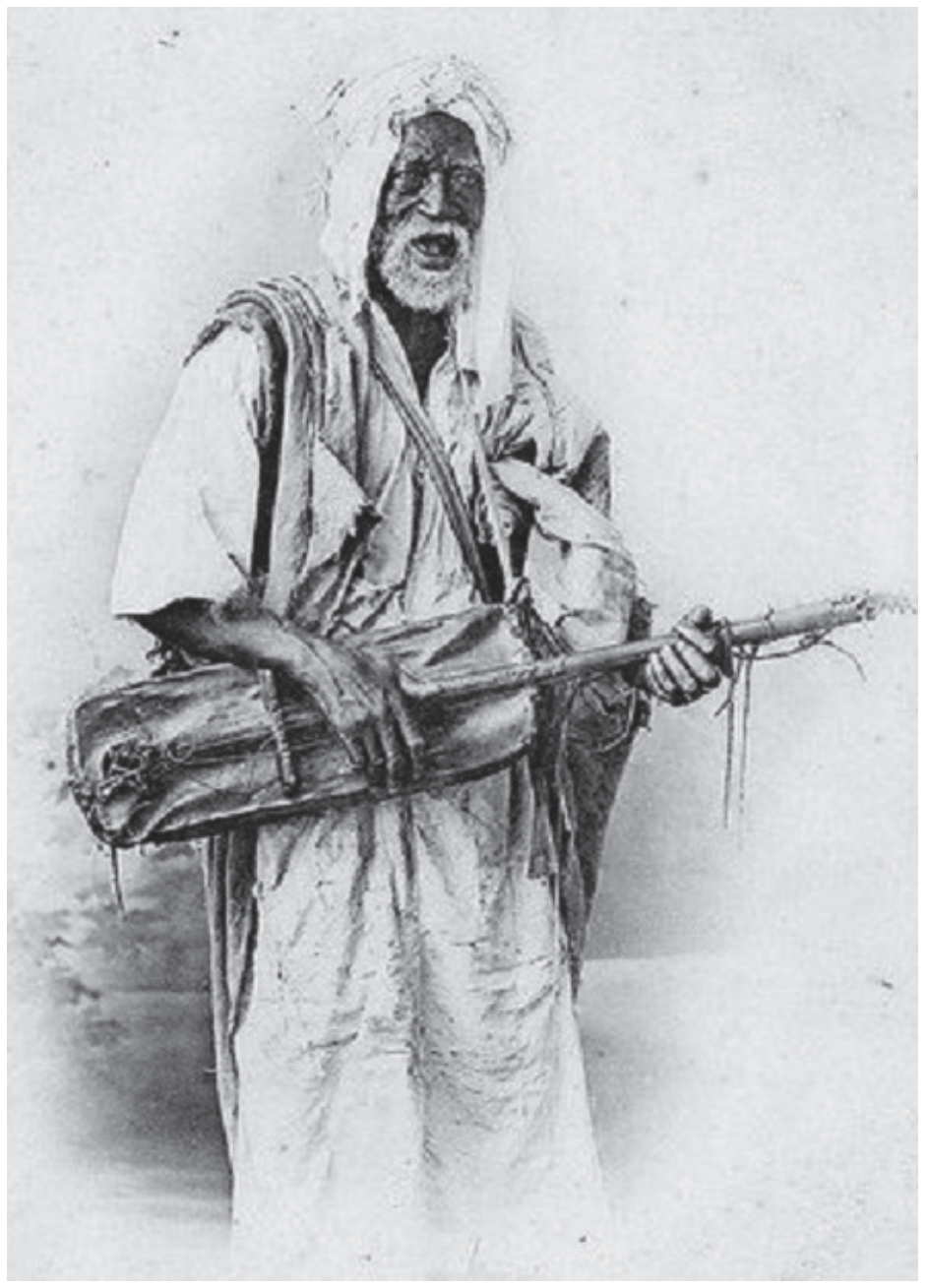

4. kép Gnawa zenész hosszúnyakú lanttal Algéria 1906 (wikipédia szabad felhasználású oldala) 
egyiptomi és az észak- illetve nyugat-afrikai lantok gunbri vagy gunibri névvel rokoníthatóak egymással és Észak-Afrika irányából terjedhettek el Nyugat-Afrikába (Farmer 1924: 158). A felvetés alapja, hogy a Magreb területén elterjedt genbri/ gunbri/guenbri/genibri elnevezések az ókori egyiptomi „n-b-r” formában jelölt lant terminus származékai és az ókori egyiptomi „n-b-r” a mai egyiptomi arab nyelvjárásban a q-n-b-r tőként (a felső-egyiptomi kiejtés szerint: '-n-b-r) : „kidomborodni”, „kiállónak lenni”, „kiduzzadni”, jelentéssel maradt fenn, ami a hangszer alakját írja le (Farmer 1938:251). ${ }^{1}$

Marokkóban a gunbri elnevezés különböző felépítésủ háromhúros hosszúnyakú lanttípusokat jelöl (Collaer-Elsner 1983:170). Bár a marokkói gunbri leginkább háromhúros, de amint azt a Néprajzi Múzeum Afrika Gyüjteményének gunbri lantja igazolja akadnak közöttük kéthúros típusok is. ${ }^{2}$ A hangszertípust leginkább a szubszaharai övezetből rabszolgaként Marokkóba került gnawa (szaharai berber dialektusban aginaw-fekete) népcsoport tagjai használják az iszlám időszak elötti szubszaharai-afrikai animista gyógyító rítusaik zenei kíséretéhez. A három húros hosszúnyakú hangszert mind ének, mind tánckísérethez egyaránt használják. A rezonátor test félbevágott tökből vagy kókuszdióból, esetleg teknőspáncélból készül, amire hangnyílásokkal ellátott bőrt feszítenek (Marcuse 1975: 432). ${ }^{3}$ A viszonylag kisméretủ gunbri lanton a húrokat egymáshoz képest sugárirányba elhelyezett facsapokkal rögzítik a hangszernyakba. ${ }^{4} \mathrm{~A}$ hengeres hangszernyakat a ráfeszített bőr membrán szorítja bele a teknőspáncélból kialakított hangszertestbe. Ez a megoldás az ókori egyiptomi lanttípusokon volt elterjedt. A marokkó gunbri jellegzetessége, hogy a Magreb és a Nyugat-Afriában elterjedt rokon lanttípusoktól eltérően a hangszernyakon nem hangoló gyürüket, hanem facsapokat alkalmaznak. ${ }^{5}$ (5.kép) A facsapok alkalmazása európai vagy belső-ázsiai hatást sejtet.

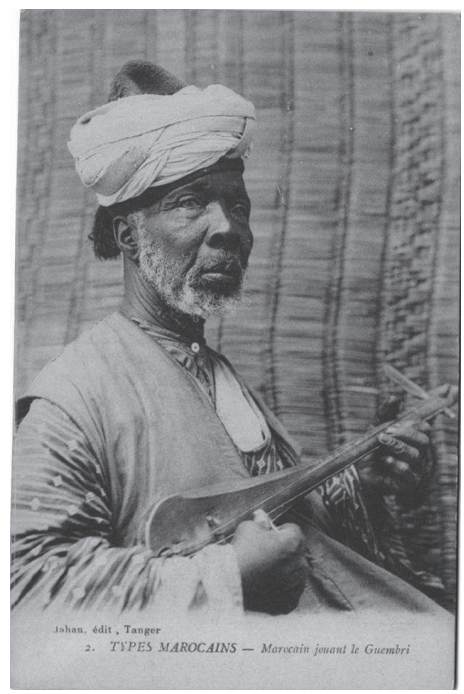

5.kép Facsapos gunbri lant 1910 Marokkó (wikipédia szabadfelhasználású oldala nyomán) 
Ez utóbbit igazolhatja, hogy az 1157-1258 közötti időszakban kimutatható egy nagyobb népmozgás Turkesztánból az észak-afrikai Magreb területére, amellyel ázsiai hangszertípusok jelenhettek meg a térségben (Farmer 1966:156-158).

A szomszédos Algériában szintén elterjedt a genbri vagy egyéb elnevezéssel gumbri, genibri hosszúnyakú lanttípus. Az Algériában használt genbri szudáni eredetü jövevény hangszer (Collaer-Elsner 1983:128). Az elnevezés különböző felépítésü hosszúnyakú lanttípusok összefoglaló terminusa. Az ovális vagy négyzet alakú fából készült rezonátortestre tevebőr membránt feszítenek a jobb rezonancia érdekében. A rezonátortesthez nyak gyanánt egy botot illesztenek. A hangszernyak végén bádog csík van, amelyet szegekkel kivernek, és ezáltal játék közben fémes hangzást érnek el. A három húrt bőrcsíkokkal vagy zsinórokkal a hangszer nyakához rögzítik, és amivel a húrok feszességét is szabályozni tudják. (6. kép) A középső húrt feszítik a legfeszesebbre, ezért ez lesz a legmagasabb hangú. A legmélyebb hangot a hangszernyaktól jobbra eső húr adja. A genbrit a jobb kéz ujjaival pengetik és a bal kéz négy ujjával fogják le a húrokat. A bal kéz hüvelykujjával a hangszernyakat tartják. Alkalmanként a zenész a jobb kezével dobol is a tevebör membránon, színesítve az előadását. A genbrit minden előadás után újrahangolják.

A Tunéziában elterjedt archaikus felépítésű, bőrgyürüs húrrögzítésű, két-három húros lanttípus a fakrún. ${ }^{6}$ Ennek a lanttípusnak a két hangnyílással ellátott, bőrmembránnal fedett hangszertestét jellemzően egy nagyobb teknősbéka (Emys leprosa) páncéljából készítik, ami az elnevezésében is visszaköszön úm. „fakrún” vagyis 'teknős' (Jankowsky 2010: 106). A hangszertípus valószínüsíthetően Mali és Niger területéről került Tunéziába. A fakrún lantot leginkább a szubszaharai övezetből hozott fekete rabszolgák animisztikus vallási hiedelmei és az észak-afrikai iszlám hagyományok ötvözetéből álló „stambali” mágikus vallási rituáléja során használ-

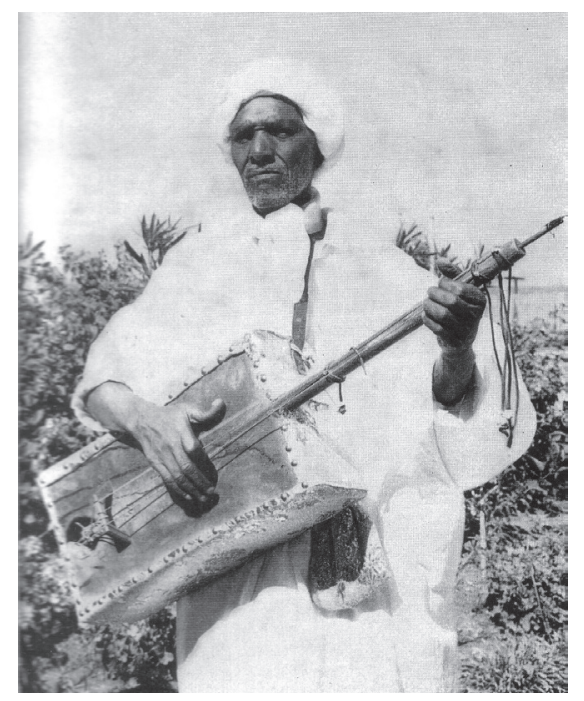

^. kép Gnawa zenész genbri lanttal, Algéria (Collaer-Elsner 1983 nyomán) 
ják, ahol a résztvevők transzba táncolják magukat. A hangszertípus felépítésében az ókori egyiptomi lanttípusokkal, illetve a teknősbékapáncél rezonátortest kapcsán az ókori görög és egyiptomi lírákkal hozható kapcsolatba, amely összességében igen archaikus hagyományt sejtet.

Felépítésében a gunbri hosszúnyakú lanttípusokra hasonlít, ám annál jóval nagyobb, átlag $1100 \mathrm{~mm}$ hosszúságú, basszus lanttípus a Marokkó északi területein a berberek és Mali déli részén a tuaregek által használt hajhuj (Nooshin 2009: 219). A szudáni övezetből Marokkóba került fekete rabszolgákból kialakult gnawa csoport zenészei szintén használják a gyógyító varászló szertartásaik során a hağhúğ vagy franciásan hajhouj lantokat (Collaer-Elsner 1983:146). A hajhuj lanttípus az egyéb marokkói hosszúnyakú lanttípusoktól eltérően nem facsapos, hanem az ókori egyiptomi lanttípusokon alkalmazott csúszógyürüs húrrögzítésủ megoldással rögzítik a húrokat a hangszernyakhoz. A hangszernyak végére egy Észak-Afrika nyugati részén, illetve Nyugat és Közép-Afrikában elterjedt, íves kialakítású fémlap van erősítve, amelynek a szélére fúrt lyukakba fémkarikák vannak illesztve, hogy a hangszerjáték alatt csengő hanggal színesítsék a hajhuj hangját. A hajhuj hosszúnyakú lantokat olykor sentir vagy sintir elnevezéssel is illetik, amely felveti a belső-ázsiai hatás lehetőségét is, azonban a belső-ázsiai hosszúnyakú lantok jellemzően facsapos húrfeszítésủ megoldással készültek.

Egy másik háromhúros, hosszúnyakú lanttípus Marokkóban a getara genawa úm. 'gnava gitár', amelynek vékony, hosszúkás, domborúhátú hangszerteste és előre hajló kulcsszekrénye van. Szintén facsapos húrrögzítésủ hosszúnyakú lanttípus a két vagy három húros átlag $500 \mathrm{~mm}$. hosszúságú lotar (Charry 2000:129). A hangszertest kókuszdióhéjból vagy félgömb alakúra faragott fából van kialakítva. Ez a lanttípus a Középső-Atlasz vonulatain élő marokkói berberek imazighen (e. sz. amázígh) 'szabad emberek' elnevezésủ alcsoportjának körében elterjedt. Úgyszintén lotar vagy lutar az elnevezése az Atlasz hegység alacsonyabb régióiban élö berberek sokkal nagyobb, átlag $1000 \mathrm{~mm}$ hosszúságú és ezáltal mélyebb hangú 3 húros hosszúnyakú lanttípusának, amelynek körte alakú hangszerteste van. A lotar hosszúnyakú lantokon az ún. ,imdyaz” dalnokok játszanak.

Mauritánia öslakói szintén a berberek imazighen alcsoportjának a tagjai voltak, akik a 3-4. század körül érkeztek a mai lakóhelyükre és valószínűsíthetően már ekkor ismerhettek egy ókori egyiptomi eredetủ hosszúnyakú lanttípust, amely a tidinit elnevezésü mai lant őse lehetett. A 15-16. század környékén a jemei eredetü Bani Hasszán arab törzs jelent meg Mauritániában és a berber törzsekkel összeolvadva kialakult az ország névadójául szolgáló mór lakosság (Gerteiny1967:128). A tidinit lanttípust leginkább az ,iggawinok” a helyi eposzénekesek használják az elöadásaik kíséretéhez (Collaer-Elsner 1983:176). A tidinit általában 4 húros, de vannak keleti szokás szerinti 5 húros változatai is. (7. kép) A vésett ornamentumokkal díszített hangszertest a commiphora africana fából készül. A hangszertest elnevezése a tazuwwa, amelynek jelentése 'hangtök', mert eredetileg tökből készült, és ezért a fából készültet is tökformájúra alakítják (Collaer-Elsner 1983:178). A kivájt rezonátortestet nem kiszárított, erősen kifeszített marhabőr membránnal fedik be, 


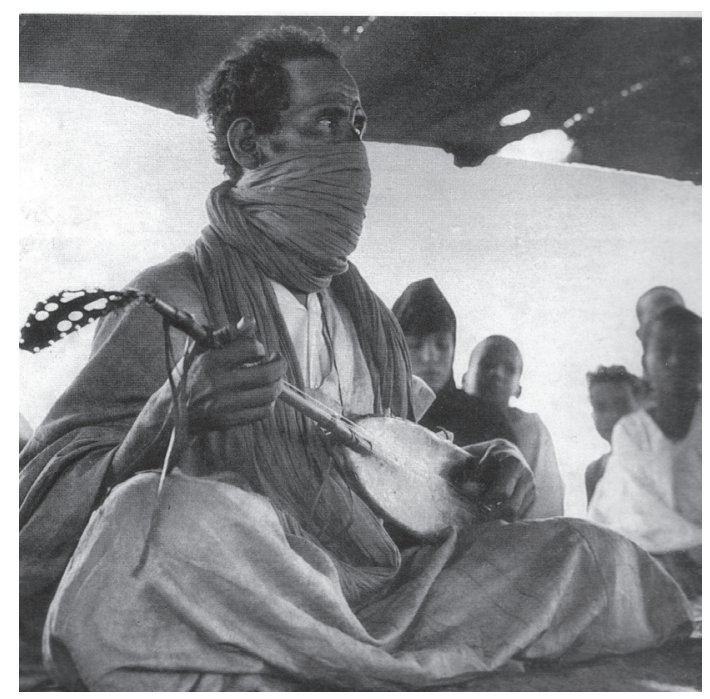

1. kép Mór iggawin énekes tidinit lanttal Mauritánia (Collaer-Elsner 1983 nyomán)

amit zsinórokkal vagy szegecseléssel rögzítenek és a hangszernyak felső részére egy csörgőt rögzítenek. A hangszernyak a membrán alatt, az alsó részen található hangnyílás közepéig fut. Három hangolókulcs a hangszernyak alján, három pedig a nyak tetején van elhelyezve. Ebből kifolyólag, a húrok különböző hosszúságúak. A hosszabb dallamhúrok középen, a rövidebb húrok pedig szélen helyezkednek el. A húrok régebben bélből, újabban müanyagból készülnek. A hangszert minden módusznál át kell hangolni. A hangszertípus elnevezése valószínüsíthetően a tuareg (önelnevezésük a kel tamasheq) népcsoport teharden elnevezésü háromhúros lantjával rokonítható és a teharden lant etimológiailag az iherden eposz énekesek elnevezésére vezethető vissza, akik az „ehad” kovács kaszt tagjai közül kerültek ki (Bebey 1999: 46).

Más vélemények szerint az ókori egyiptomi lantok nem Észak-Afrika irányából terjedtek el Nyugat-Afrikába, mert például Algériába a nyugat-szudáni eredetü gnawák által Marokkó irányából történhetett az átvétel (Charry 1996: 4). Ezen hipotézis alapján az ókori Egyiptomból dél felé Kush és Meroe királyságok irányába terjedtek el a lantok és Nyugat-Afrikába a nyugat-szaharai kereskedelem által jelenhetett meg a hangszertípus. Emiatt a lantok a nyugati Száhel-övezet és az északi szavanna régióban (Mauritánia, Szenegál és Mali) lokalizálódnak és elsősorban a birodalomépítő muszlim népek körében jellemzőek. Valószínüleg nem véletlen, hogy ezek a népek - maninka, mandinka, bambara, xasonke, wolof, soninke, fulbe és mór (moor) - mind egy nagy földrajzi régióból származnak, amely a legkorábbi ismert nyugat-afrikai birodalom az ősi Ghána (? - Kr.u. 11. század) hatása alatt állt (Charry 1996:5). Ráadásul a genbri, gunbri stb. elnevezések a 19. századnál korábbról nem adatolhatóak, ezért a hangszertípus és vele együtt az elnevezés a soninke és bambara népcsoportok területéről származó gnawa rabszolgák által is 
elterjedhetett (Charry 1996: 12). Ebből kifolyólag a soninke népcsoport gambare elnevezésü lant típusa lehetett az észak-afrikai gunbri lantok elöképe, amely a fonológia vizsgálatok alapján a wolof népcsoport xalam (khalam) lanttípusának elnevezésével is rokonítható, amelyben az „r” hang „l” és a „,” pedig „m” formát öltött (Hause 1948, 58).

A soninke orális tradíció szerint a gambare lant a griotok (jaare) legrégebbi hangszere, amit a „wagadu korszakból” származtatnak (Charry 1996:13). ${ }^{7}$ Maliban a soninke népcsoport hösepikai énekeseinek ngoni lanttípusát az epikus hagyomány a Ghánai Birodalom egyik uralkodójának kegyetlen harcos fiától Gasszirétől származtatja. Ez alapján „A minden ellenségét lekaszaboló és örök hírnévre vágyó Gasszire egy napon a fogoly madár (Rollulus rouloul) „dauszi” énekét hallgatva ráébredt, hogy tettei feledésbe merülnek, ezért elment a helyi kovácshoz és megkérte, hogy készítsen neki egy lantot, amelyen ő is eljátszhatja a „dauszi dalt" és általa hírneve örökre fennmarad. ${ }^{8}$ Azonban ahogy azt a kovács is megjósolta a lant néma maradt, mert önmagában nem tud „,dalolni” hisz nincs szíve. Ezért Gasszire a kovács tanácsára az elkövetkező csatákban a lantot a hátán hordta és az átitatódott a csatában elhulló fiai vérével és Gasszire verejtékével, könnyeivel. (Frobenius-Fox 1938: 115-116). Így vált a lant Gasszire sorsának a részévé és mivel már volt „szíve” gyönyörủen szólt. Gasszire pedig hercegből hősepikai énekessé lett és a griotok által a „dauszi dal” mindmáig él.

Mali északnyugati részén a soninke népcsoporthoz tartozó marakák körében gyüjtő Frobenius az énekmondók három csoportját különíti el úm. a diare, a gesszere és a garanke, akik közül a legrégebbi csoport a bőrmegmunkálással is foglalkozó garankék, a legkiválóbb énekesek a diarék és a harmadik csoport a kifejezetten alacsony társadalmi presztízzsel rendelkező gesszerék (Frobenius 1921: 37). Ez utóbbi csoport jellemzően a különböző királyi fesztiválok, temetések, katonai hadjáratok és koronázások alkalmával jó pénzért, akár történelmileg nem hiteles vagy családfahamisító énekeikkel nyújtott alkalmi szolgáltatásokat azoknak, akik megfizették őket ezért. Mindebből kifolyólag a gesszeréket egyáltalán nem tisztelték. Ezzel szemben a diarék énekes csoportja a hőseposzok előadói, akik emellett az uralkodó tanácsadójaként vagy diplomáciai küldöttként is funkcionáltak komoly megbecsülésnek örvendtek (Frobenius 1921: 43). (8. kép)

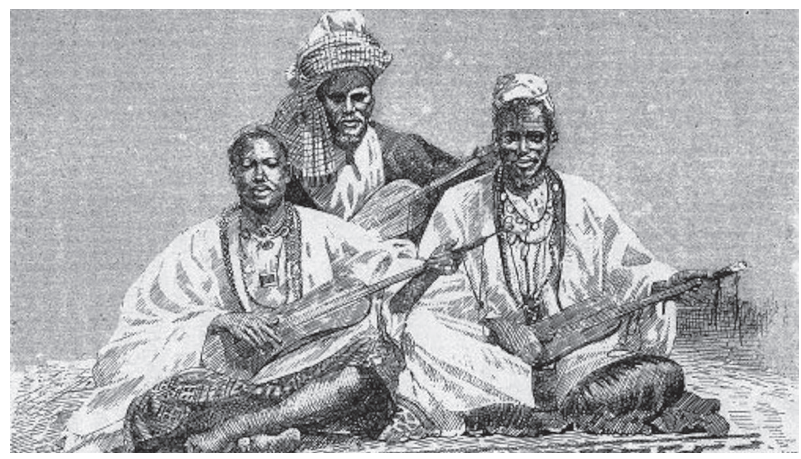

8. kép Sambala király udvari griot énekmondói Medina, Mali 1890 (wikipédia szabad felhasználású oldala) 
A későbbi antropológiai vizsgálatok azonban nem igazolták Frobenius megállapításait, mert a soninke diare, ami a mandinka djeli szó változata, funkciójában nem különbözött a nyugat-afrikai griot -októl, akik bár királyi énekmondóként akár komolyabb jutalmazásban is részesülhettek, de a társadalmi ragjuk egységesen kifejezetten alacsony presztízsủ volt (Jablow 1984: 521). Habár a soninke diarik más griot csoportokhoz képest a nemesek kíséröiként szokatlanul magas megbecsülésben lehetett részük, ez csak kb. olyan jellegü különbség lehetett, mint amelyen az úri kaszinók cigányzenészei és a falusi cigányzenészek között fennállt. Mert bár az úri kaszinók cigányzenészei, mint például a Liszt Ferenc által is nagyra tartott Pintér Pál, aki Rácz Pali bandájával Franciaországban és Angliában koncertezve akár koronás fök elött is játszhatott, de ettől még nem emelkedett a nemesi rend tagjai közé (Markó 1896: 74). Ezért zenész kasztként a griotok társadalmi presztízse is a lehető legtávolabb állt a helyi nemességétől, mert például a mandinka társadalomban a kovácsokkal és a fazekasokkal együtt a rabszolgák kasztjába tartoztak (AppiahGates 2010: 135-136). Nigéria északi részén a hausa népcsoport körében a griotokat egyszerü iparosoknak tekintik, akik saját bevallásuk szerint is a zenére egyfajta szolgáltatásként tekintenek és saját örömükre nem zenélnek (Ames 1973: 152). Habár a modernizálódó világban az ősi hagyományos tiltások lassan érvényüket vesztik, de a griotok társadalmi megítélése továbbra is őriz negatív vonásokat, mert nem nagyon házasodhatnak a kasztjukon kívül és haláluk esetén a „föld beszennyezésének” elkerülése érdekében még mindig gyakori, hogy odvas baobab fákba temetik őket (Conrad-Frank 1995:4-7). ${ }^{9}$ Hasonló házassági tilalom vonatkozott a haddad-ok vagyis a kovácsok kasztjára és összességében a griotok ellentmondásos megítélésének hátterében az iszlám megjelenésével együttjáró társadalmi átrendeződés állhat, amelynek során a korábbi magasabb presztízsü, az animista hittel is összefondott gyakorlatú kézmúves csoportok a már muszlim társadalom aljára csúsztak (Weekes szerk. 1984: 1:310).

Ami a griotok eredetét illeti, a Guineában és Maliban élő mandinkáknál és a velük rokon nyelveket beszélő népeknél a származásukat egy bizonyos Szurakata Bum Malikra vezetik vissza, aki Mohamed próféta egyik ellensége, illetve a későbbiekben a híve volt és amely eredetmonda alapja Szuraka ibn Málik ibn Dzsusam története lehetett (Szombathy 2021:102). Az iszlám hatását tükrözö, arabokra viszszavezetett fiktív eredetmondával ellentétben valószínübb, hogy a nyugat-afrikai királyságok vadász társaságainak zenész rétegéből alakulhatott ki az örökletes zenész griotok osztálya (Frobenius 1921: 23). Ezek az eredetileg hárfás zenészek a szavannai vadásztársaságokból szerveződhettek valamikor a 16. században, amikor a Szongháj Birodalom elhalványította a Mali Birodalmat és megerősödött a mande hatás és ezzel együtt a hárfákat kiszorították az akkor megjelenő lantok (Bird 1972: 291-292). Azonban a királyi udvari zenészek már korábban is tevékenykedhettek, mert a berber származású utazó Ibn Battuta már 1352-ben beszámol arról, hogy a Mali udvarban tett látogatása alkalmával professzionális udvari zenészeket látott, akik a király és a nemesség zenei igényeinek kiszolgálói voltak (Tang 2007:1). Az első djeli (dzseli) családok nevei is fennmaradtak pl. Diabate, Kouyate, Suso és 
Sissokho...stb, amely családok leszármazottai napjainkig űzik a zenészmesterségüket (Charry 2000:375-382).

A vadászok íjhárfáiból és a hosszúnyakú lantok kereszteződéséből kialakított donso ngoni hárfalanton kizárólag vadászok játszottak, akik a vadászati technikákról és nagyobb vadászati sikerekről szóló dalaik, illetve a vadászathoz alkalmazott mágikus szertartások kíséretéhez használták a hangszertípust (Brauer-Benke 2009:107). (9. kép) A „ngoni” elnevezés a senufo-tagba nyelvekben a húros hangszerek jelölésére szolgál. Mali nyugati részén fekvő Nioro városából származtatják a ngoni lantot, ami a fulbe népcsoport által terjedt el Nyugat-Afrikában (Charry 2000:18).

A djeli ngoni felépítését tekintve valószínüsíthetően az ókori egyiptomi lantok leszármazottja lehet, ami a berber öslakosság által terjedt el a Szaharai övezetben is. Az eredetileg egyhúros pásztorhangszer a malinke eposz énekesek által lett négyhúrossá fejlesztve és ezért lett az elnevezése djeli ngoni. A Néprajzi Múzeum Afrikai Gyüjteményének Guineából származó hangszere a típus jellegzetes morfológiai jegyeivel rendelkezik úm. ovális, vályúszerủen kifaragott fából készült, amelyet kiszárított állatbör membránnal fednek be. ${ }^{10} \mathrm{~A}$ bőrmembránt vagy benedvesítve hagyják, ami száradás által feszül rá a hangszertestre, vagy hozzászegelik a hangszertest pereméhez. A hangszernyak faragás vagy fúrtlyuk nélküli illesztéssel van a hangszertestre helyezve és a bőrmembránon vágott nyílásba bújtatva és a hangszernyakat tulajdonképpen a börmembrán szorítja rá a hangszertestre. A muzikológusok ezt a típusú megoldást nevezik ,internal spike lute” vagyis belső nyakrögzítésü lanttípusnak (Hartong 2006:168).

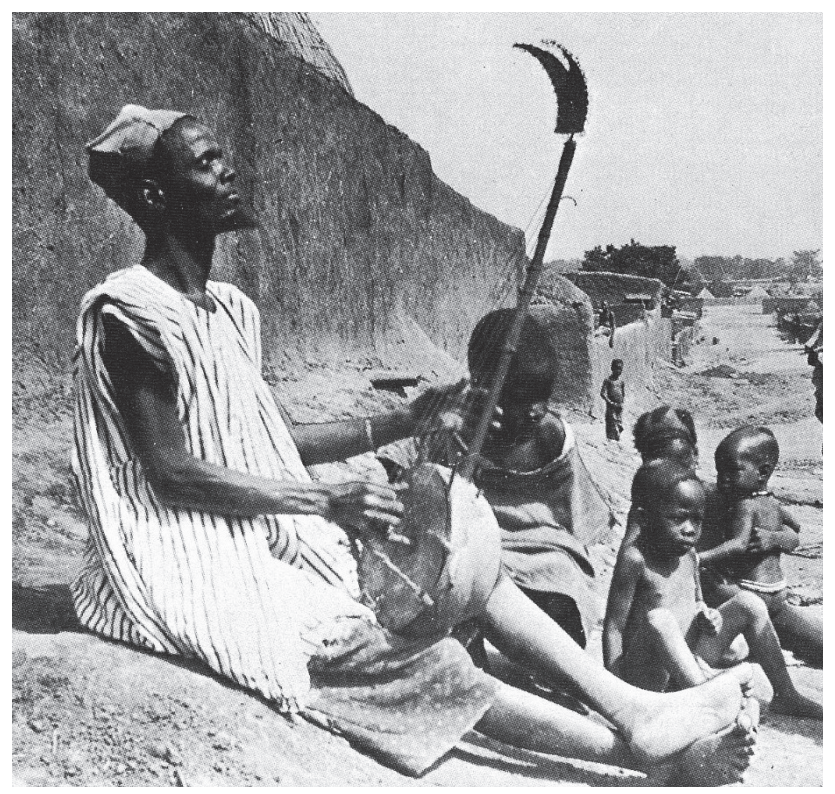

^9. kép Falusi griot donso ngoni hárfalanttal 1908 Mali (wikipédia szabadfelhasználású oldala nyomán) 
Habár a zenészkaszt elnevezése gyakran a hangszerelnevezésekben is tükrözödött pl. gawlo vagy djeli ngoni, de összességében a különböző nyelvü népcsoportok griot lanttípusainak külön elnevezése alakultak ki úm. mande koni, wolof xalam, soninke gambare, fulbe hoddu és a moor tidinit és a többféle elnevezés egyben arra is rámutat, hogy a hangszertípus már régen jelen lehet a térségben és több különböző irányú átvételt sejtet (Charry 1996:9). Ezért a morfológiai adatok áttekintése alapján a legyező alakú húrtartó lábas lanttípusok a különböző etnikai csoportok griotjai által kerülhettek Nyugat-Afrikába, míg a másik típus a hengeres húrtartólábas lanttípusok, aminek a rezonátor teste félbevágott tökből készült a fulbe migrációval Észak-Szenegál irányából terjedhetett el Kamerunba is (Charry 1996:6-7). További különbség, hogy a griot lantok hangszerteste mindig fából készült, míg a másik típus készülhet fából, tökből vagy újabban fém dobozból is. Ez utóbbi típus egy-két húros, míg a griot lantok legalább háromhúros típusok.

Nyugat-Afrikából a 14. század óta adatolható a lantok jelenléte, Al-Umarí 133738 körüli leírásában a Mali király lovon érkezett és napernyőt tartottak a feje fölé és mögötte dobosok, gitárosok (tunbúr) és fémből készített trombitákkal zenélő muzsikusok jöttek (Al-Umarí 1981: 266-67). Ibn-Battúta 1355-56-os leírásában az énekesek a szultán mögött jöttek arany és ezüst húros lantokkal (qunburi), amikor Maliban egy királyi ünnepségen vettek részt (Ibn-Battuta 1981:291). A korábban tárgyalt etimológiai fejtegetésekkel ellentétben az sem kizárt, hogy az Ibn Battúta leírásában szereplö Mali birodalomban használt q-n-b-r lant terminus a mande népcsoport konibara lanttípusával azonosítható, amelynek etimológiája „koni”-ujj és „mbara”-tök, illetve az Al-Umarí leírásában kapcsolatba az eredetileg q-n-b-r terminus a későbbi átírások folytán vált volna t-n-b-r formájúvá és így azt a szerzők később azonosították a perzsa eredetü tunbúr-ral (Charry 1996:15). Ezért a nyugat-afrikai lant elnevezések összehasonlító etimológiai vizsgálata (mandinka konondingo-kontingo, wolof baram-xalam, fulbe hondu-hoddu ) alapján az ujj és a lant elnevezések öszefüggései azt feltételezik, hogy a hangszertípus igen régen jelen van a térségben és ebből kifolyólag, inkább ezen elnevezések képezhették alapját az észak-afrikai gunbri típusú terminusoknak, amely a hangszertípussal együtt a gnawák-kal együtt került a Magreb térségbe (Charry 1996:15). Ezt támaszthatja alá a marokkói getara genua vagyis „gnava gitár” elnevezés amelyet, amint az a nevéből is kitetszik, csak a fekete gnawák használnak (Collaer-Elsner 1983:70). A hangszernyak végére szerelt hajlított fémlapra erősített csörgőkarikák szintén a Nyugat és Közép-Afrika nyugati területein elterjedt hangszereken alkalmazott jellegzetes megoldásnak tekinthetőek.

A nyugat-afrikai lantokon és hárfákon alkalmazott fémlemezes csörgő NyugatAfrika szerte elterjedt és ebből kifolyólag valószínűsíthető, hogy a gnawak által terjedhetett el a Magreb területein is (Charry 1996:5). Ez a lemezes csörgötípus leginkább a Magreb területére jellemző és Nyugat- és Közép-Afrika néhány területétől eltekintve, más területekről nem adatolható az elterjedése. Ezért az átvétel irányát csak akkor lehetne megnyugtató módon tisztázni, ha történeti adatokkal lehetne bizonyítani, hogy ez a hangkeltő eszköz a nyugat-afrikai térségből korábbról datál- 
ható, mint a Magreb térségéből. Ráadásul a lemezes csörgő használata az Atlasz magas régióiban élő berberek slúh nevű alcsoportja és a Mali déli részén élő tuareg népcsoport hosszúnyakú lanttípusain egyaránt megfigyelhető, ami azt a lehetőséget is felveti, hogy a lemezes csörgők hosszúnyakú lantokon való alkalmazásának a szokása akár még a tuareg népcsoport nomadizáló tevetartó életmódjának kialakulása előtti időszakra tehető.

A djeli ngoni lanttal megegyező felépítésủ a Szenegálban és Gambiában elterjedt három húros, 'beteg' jelentésủ kurango, amit a mandinka tradíciók szerint betegségek gyógyítására használtak (Coolen 1983:482). A hangszerről az első leírás 1682-ből Szenegálból ismert, ahol kiemelik a gyógyító funkcióban való alkalmazását (Sieur Le Maire 1965:128). Szintén rokontípusnak tekinthető a Maliban, Gambiában, Nigerben és Szenegálban elterjedt xalam vagy khalam, ami a wolof, a serer, a tukulor, mandinka és a fulbe népcsoportoknál elterjedt, ahol a profi eposz énekesek a griotok jellegzetes hangszertípusa (Charry 2000:164). (10. kép) Ez a lanttípus valószínűleg a Maliban élő bambara népcsoporttól eredeztethető, akiktől déli irányba a malinke, illetve északi irányba a fulbe és a tukulor, majd innen is tovább terjedve a wolof és a serer népcsoportok körében is megjelent. A wolof xalamkat-ok vagyis a helyi a profi énekesek a társadalmi hierachiában a szabadnak született „nyeenyo”-k a kézmúvesek kasztjába tartoznak (Coolen 1983:483). A xalam lantokon 2 dallamhúr és 2-3-4 oktávhúr található és a jobbkéz hüvelyk és mutató ujjaival pengetik, míg a balkéz ujjaival csak a két dallamhúrt fogják le. A többi oktávhúrt hárfaszerủen pendítik meg és hagyják szabadon rezegni. A xalamkat-ok a xalam lanttípuson belül

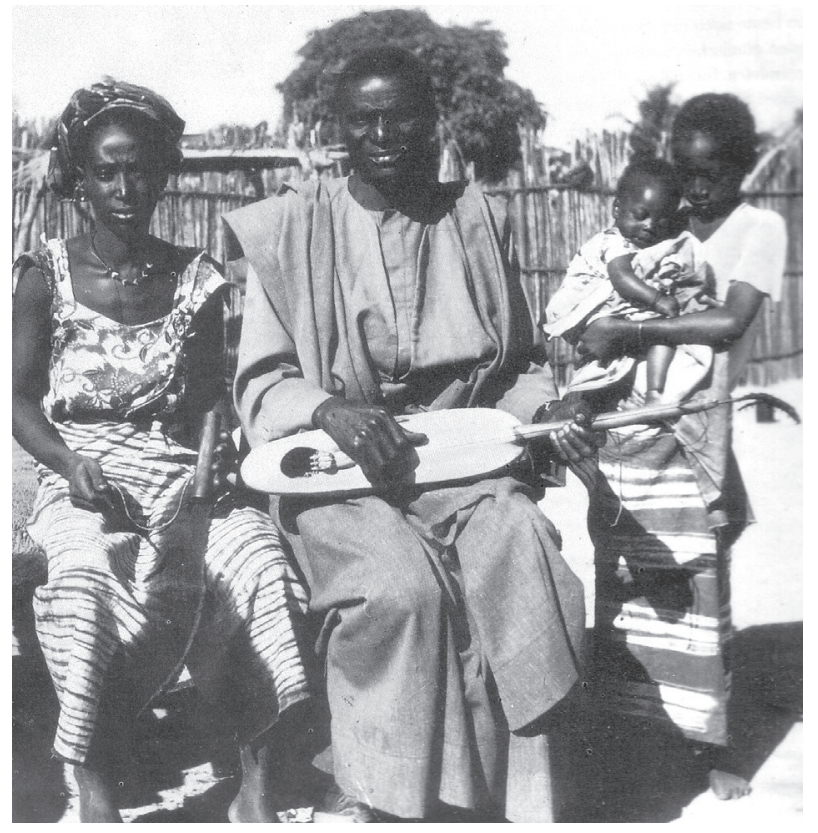

^10. kép Griot énekes kurango lanttal Gambia (Kubik 1989 nyomán) 
még 4 különböző méreteiben és ebből adódóan hangolásában eltérő altípust is megkülönböztetnek úm. bopp, nderr bopp, nderattul és jox (Coolen 1983:484). (11. kép)

A xalam lanttal rokonítható a fulbe hoddu, amely elnevezéssel kapcsolatban már korábban felmerült, hogy az arab úd terminus átvétele lehet (Erlmann 1986:10). A fulbék hoddu lantja azonban egy hosszúnyakú lanttípus, amely felépítésében rokonítható a környező népek lanttípusaival és egyáltalán nem jellemző, hogy egy új hangszernév elterjedne a hangszertípus átvétele nélkül. Ezért valószínú, hogy a környezö népek lant elnevezéseihez hasonlóan a fulbe hoddu lant terminus is a „hondu” vagyis az ujjak jelentésủ kifejezéssel hozható kapcsolatba (Charry 1996: 9). A xalam lanttal további rokon típusnak tekinthető a Togó északi területén a kabiye és a kotokoli népcsoportok körében elterjedt kéthúros lawa (Kubik 1989: 166). Az ovális tökből készült hangszertest antilopbörrel van fedve és a hátoldalán bőrrojtok találhatóak. A viszonylag rövid nyakon nincsenek érintők. (12. kép) A húrok rögzítése ókori egyiptomi előképekre vezethető vissza. A lawa lant togói megjelenése, északi-szudáni muszlim hatást mutat, mert a hangszertípus a hausa népcsoport molo elnevezésü, hosszúnyakú lanttípusával rokonítható (Kubik 1989: 166). A húrokat a jobb kézben tartott plektrummal pengetik és a bal kéz középső és gyürüs ujja között tartott botdarabbal fogják le a nyak fölött. A lawa lantot szólóhangszerként a zenész saját éneke kíséretére használja. Szintén rokon hangszernek tekinthető a Kamerun északi részén a kotopo (kotofo/koutin/peer/potopo) népcsoport által használt mulore elnevezésü, egyszerü felépítésü, hosszúnyakú lant, amelynek a hangszerteste ovális tökből van kialakítva és a tetejére erősítik a

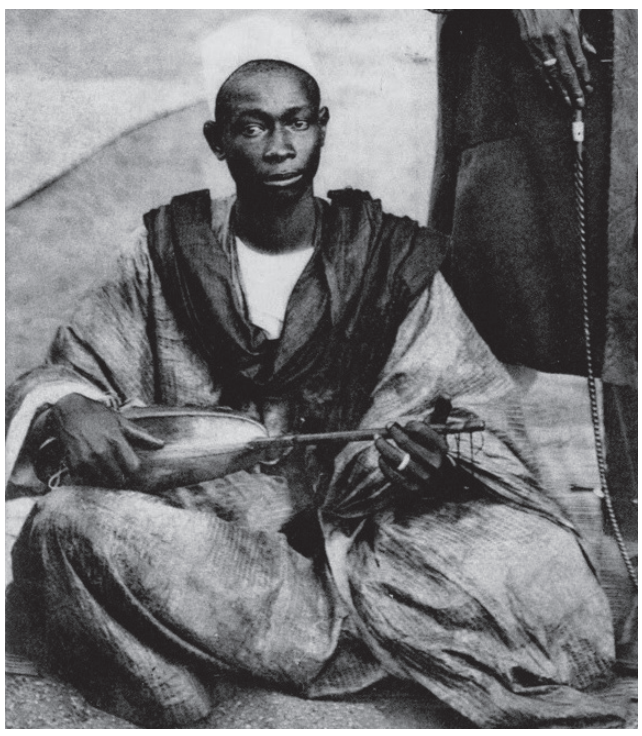

^11. kép Griot énekes xalam lanttal Szenegál (wikipédia szabad felhasználású oldala)

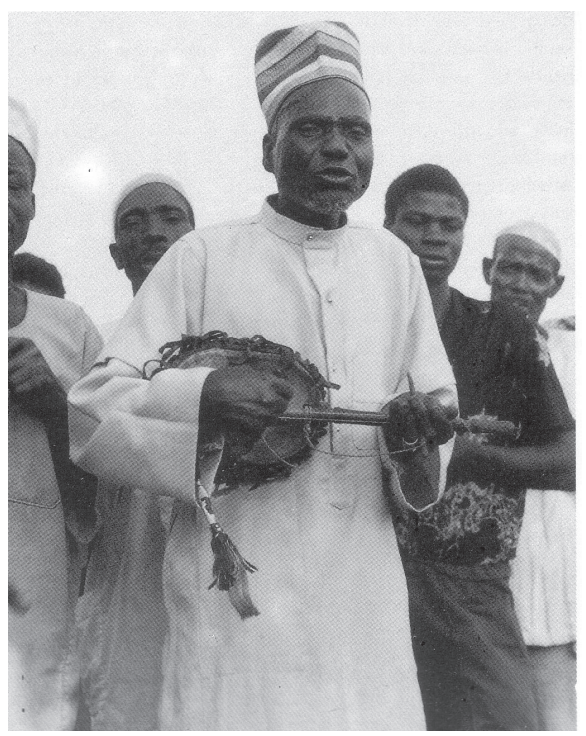

12. kép Griot énekes lawa lanttal Togo (Kubik 1989 nyomán) 
rendkívül vékony, a hangszertestnél alig hosszabb hangszernyakat. (13. kép) A húrok gyürükkel vannak a nyakra rögzítve és azokat elforgatva lehet a húr feszességét szabályozni. A hangszernyak végére lapos fémlap van erősítve, aminek a szélén fúrt lyukakba csörgő vasgyürüket erősítettek. A hangszer jelenléte a hausa népcsoporttal való kapcsolatra utal (Kubik 1989:86). Nigériában a hausa népcsoport kéthúros hosszúnyakú lantja a garaja amit leginkább az utazó kereskedők használtak, ezért más, környező népcsoport is átvette tölük a hangszertípust (Kubik 1989). A fából készült rezonátortest lapos kialakítású és ovális vagy levél alakú, amelyre vékony fedölapot szögeznek. A hangszernyak egy vékony, egyenes rúd, amely a hangszertest közepéig nyúlik. A húrok és a fedőlap között félgömb alakú húrtartó helyezkedik el. A hengernyak vége villaszerü kialakítású és erre hurkolják rá a húrokat. (14. kép)

Nyugat-Afrikában helyi jellegzetességként a hosszúnyakú lanttípusokon nagyméretü, kerek kobaktökből kialakított hangszertesteket alkalmaztak, ilyen lanttípusok Szenegálban, Gambiában és Bissau-Guineában a jola (yola/dyola) népcsoport körében elterjedt akonting, a manjaco (mandyako/manjago) népcsoport által használt buchundu, a papei busunde és a balente (balanta/balanta-brassa) kisinta. Ezeket a lanttípusokat a Karib térségbe és az USA-ba hurcolt rabszolgák ott is elkészíthették és a kialakuló bendzsó típusú lantok előképéúl szolgálhattak (Jägfors 2003:26-33). Már Mungo Park 1799-es leírásában szerepel egy 3 húros gitárszerủ hangszer, aminek koonting a neve (Park, 1983: 213-14). Ez valószínúleg a mandinka kotingo vagy a jola akoting lanttípusokkal azonosítható. (15. kép) A jola szóbeli hagyomány szerint az akonting lant Szenegál déli részéről a Casamanca folyó vidéki Kanjaka

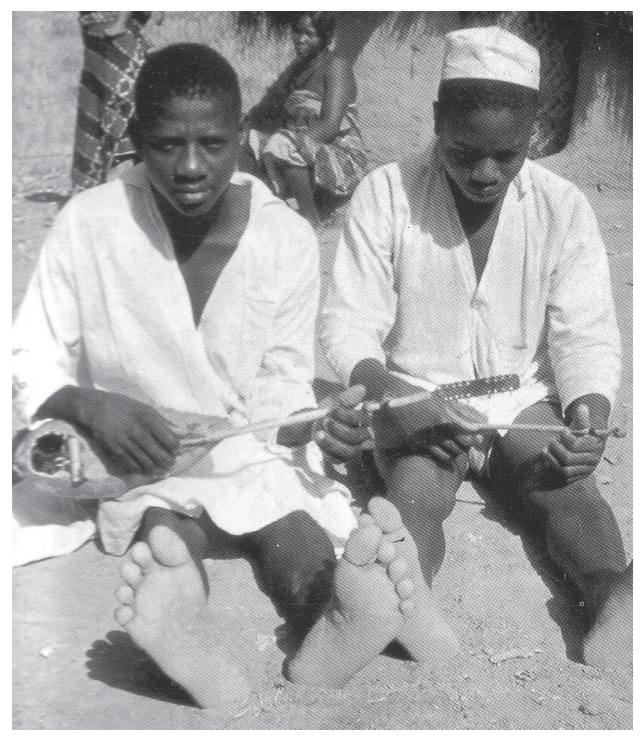

\13. kép Kotokoli fiatalok mulore lanttal Kamerun (Kubik 1989 nyomán)

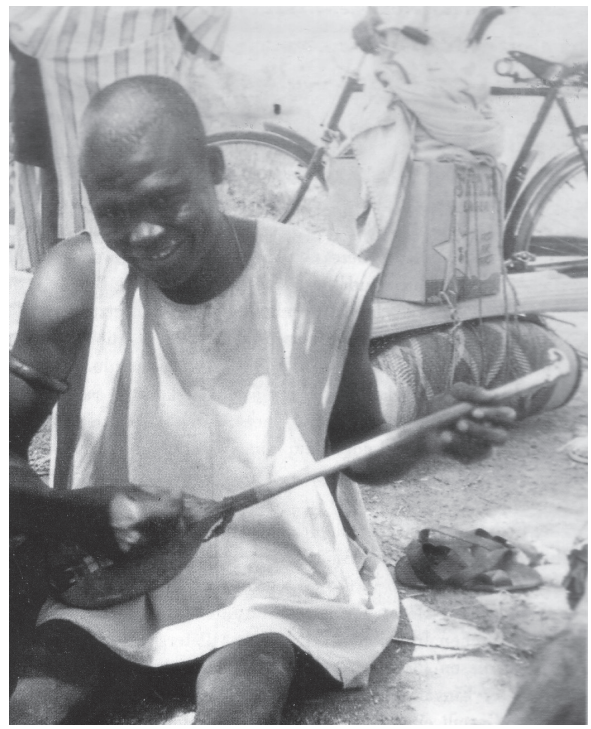

\14. kép Hausa zenész garaja lanttal Nigéria (Kubik 1989 nyomán) 


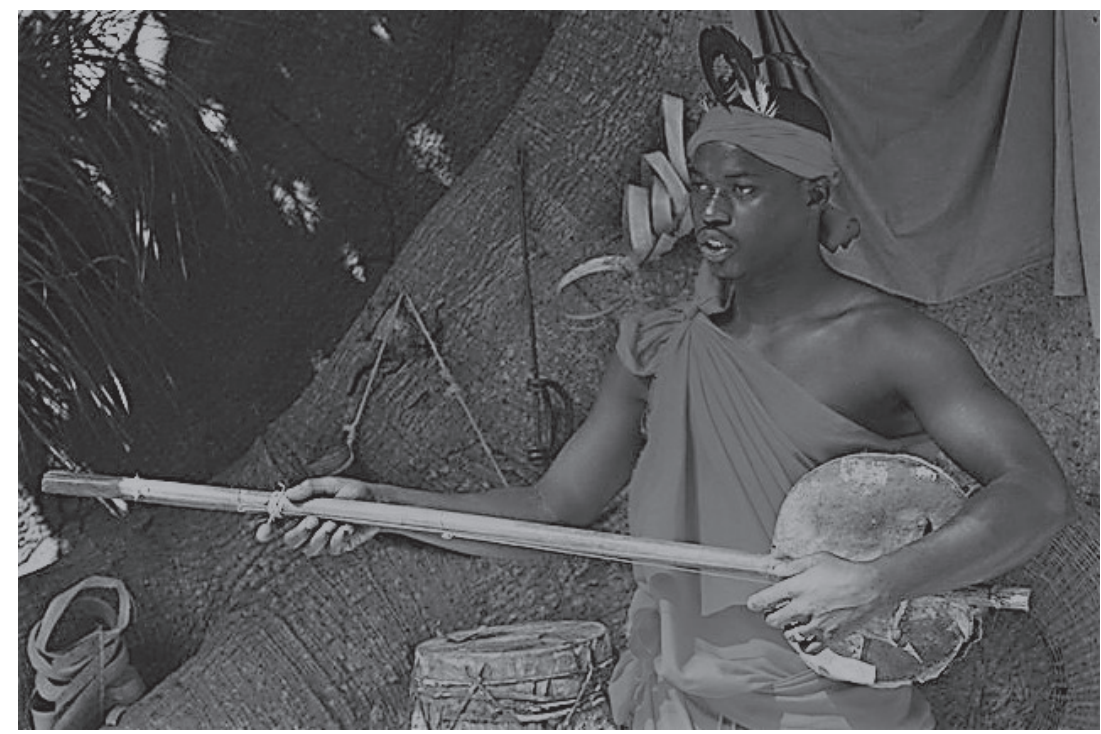

^15. kép Jola zenész akonting lanttal (wikipédia szabad felhasználású oldala nyomán)

faluból származik A falu elnevezése a húrok hangolására utal. A ,kan” a skála ötödik hangja, a ,jan” az alaphang és a „kan” fél hanggal leszállított hetedik hangja úm. dGF (Schaffer 2005:334). Az akonting hosszúnyakú lant jellegzetessége, hogy azon két hosszú dallamhúr és egy rövidebb rezonáns húr van kialakítva. A későbbi öthúros bendzsón szintén megmaradt ez a megoldás, ahol egy rövidebb, a hüvelykujjal megszólaltatott rezonáns húrt alakítottak ki. Fontos azonban kihangsúlyozni, hogy a wikipédia szócikkei által is terjesztett közkeletü vélekedésekkel ellentétben az Amerikába hurcolt afrikai rabszolgák nem vitték magukkal a hangszereiket. ${ }^{11}$ Legfeljebb csak azok formai jellegzetességeit próbálhatták megjeleníteni az újonnan elkészített hangszereken, amelyek formai jellemzőit egyéb hasonló funkciójú hangszerek, jelen esetben a korai portugál bandore vagy a spanyol bandurria lanttípusok is befolyásolhatták. (16. kép)

Habár a hosszúnyakú lantok morfológiája egyértelmúen bizonyítja azok ókori egyiptomi származását, a nyugat-afrikai elterjedésük csak jóval később történhetett, máskülönben a bantu expanzióval a hárfákhoz hasonlóan elterjedtek volna a közép és kelet-afrikai térségben is. Közép-Afrikából azonban nem adatolható a lanttípusok elterjedése és a kelet- és dél-afrikai szélesebb hangszernyakú lanttípusok nem rokoníthatóak az észak és a nyugat-afrikai rúdnyakú lantokkal.

A bendzsóhoz hasonlóan a Dél-Afrikában használt ramkie, kézzel készített népi lant is a korai portugál lanttípusok jellegzetességeit mutatja és valószínüleg az indiai Malabar partról származó rabszolgák által kerülhetett Dél-Afrikába (Kirby 1968: 255). Ahol először a koikoi (hottentotta) népcsoportnál mutatható ki a hangszer jelenléte, akiktől a szanokhoz (busman) majd a bantu nyelvü népcsoportokhoz is átkerült. A ramkie a legkorábbi Charles Bell féle 1834-es ábrázoláson még kifeje- 


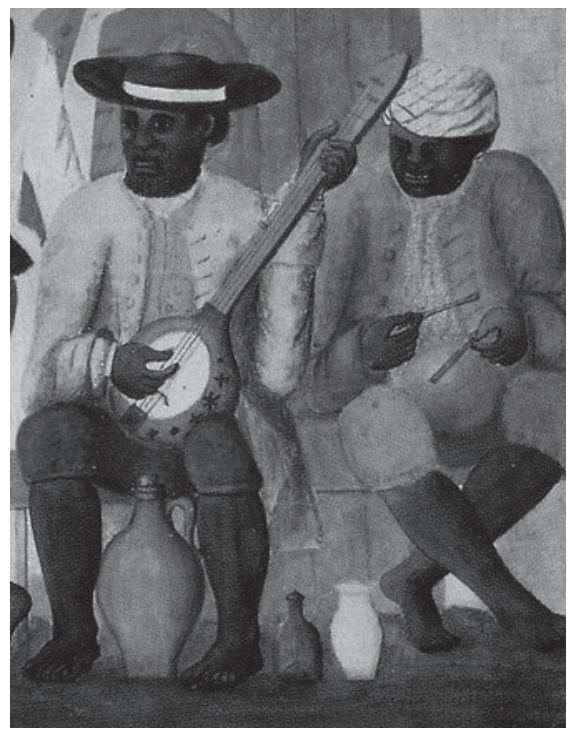

^16. kép Korai bendzsó ábrázolás DélKarolinából, 1785-1795 (wikipédia szabad felhasználású oldlala nyomán)

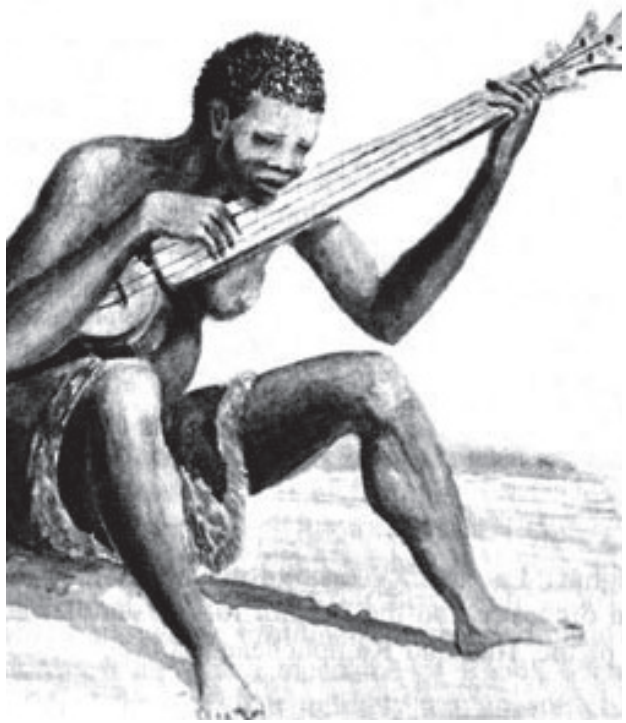

^17. kép Ramkie gitár korai ábrázolása 1834böl (Kirby 1968 nyomán)

zetten hosszúnyakú lantféle hangszer (Kirby, Percival R 1968: plate 73). (17. kép) A későbbi típusai között már kifejezetten rövidnyakú példányai is megtalálhatóak. A hangszertípus legkorábbi említése 1787-ből ismert (Mentzel 1787:518-519). A ramkie elnevezés valószínüsíthetően a portugal rabequinha úm. rabeca pequena (kishegedü) elnevezésből eredeztethető (Kirby 1968: 249). A ramkie három vagy

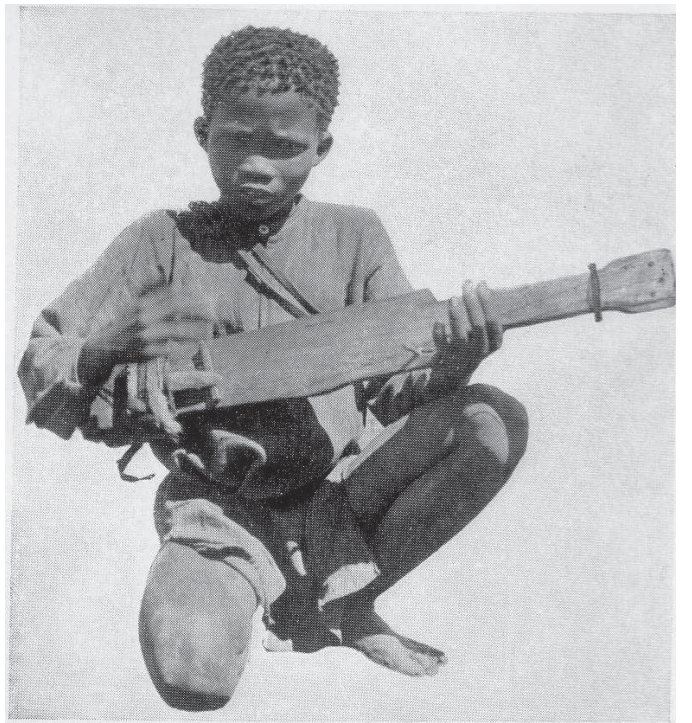
négyhúros, érintők nélküli, hoszszúkás hangszertesttel ellátott, primitív felépítésü hangszer, amely egy fából lett kifaragva és hangszertestként bör vagy tökrezonátort erősítenek. (18. kép) Az 1960-as években a bör vagy tökrezonátoros típusok mellet már megjelentek a konzervdobozból kialakított rezonátortestű típusok,

$<$ 18. kép Ramkie gitár bör rezonátorral Dél-afrikai Köztársaság (Kirby 1968 nyomán) 
amire utólag erősítik hozzá a hangszer nyakát. (19. kép) A ramkie lantok a Délafrikai Köztársaságon kívűl Namíbiában és Botswanában is elterjedtek. Zambiában, Malawiban és a Kongói DK déli részén egészen nagyméretű, műanyag kannából készített, vagy egy hengeres dob hangszertesttel kiegészített, basszus változatai is kialakultak, mint például a kalindula vagy karindula. (20. kép)

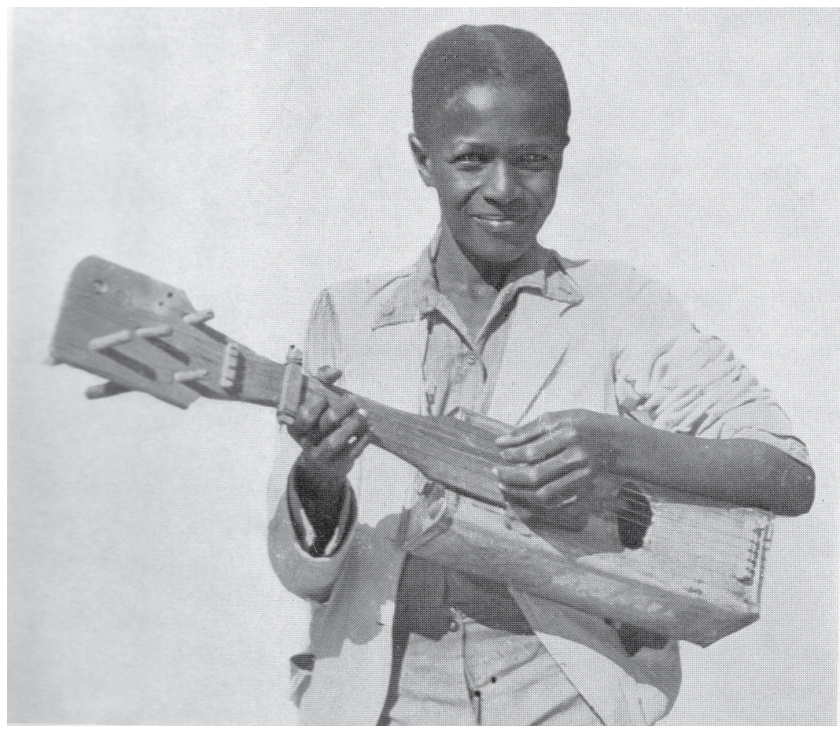

^19. kép Ramkie gitár fémdoboz rezonátorral, Dél-afrikai Köztársaság (Kirby 1968 nyomán)

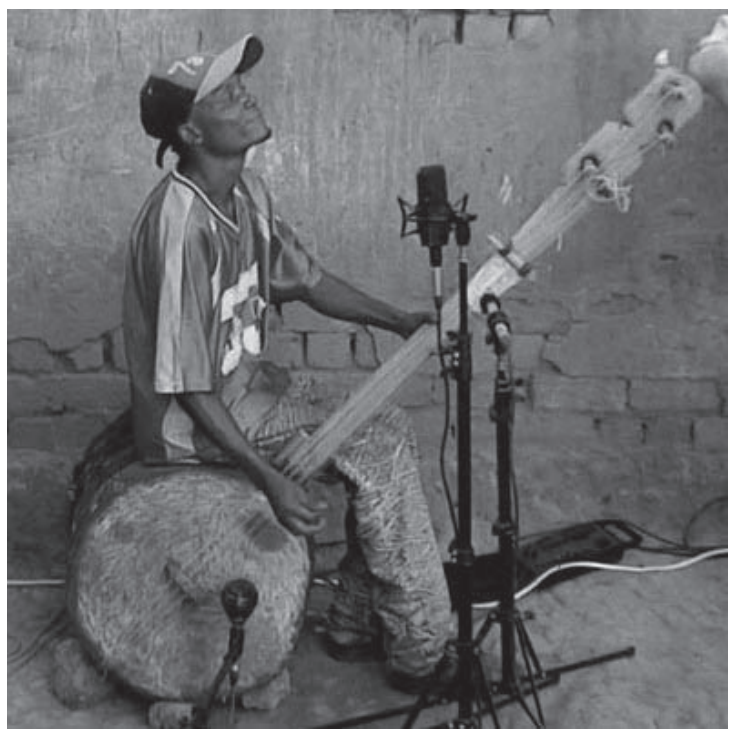

^20. kép Karindula basszus lant Kongói DK (wikipédia szabad felhasználású oldala nyomán) 


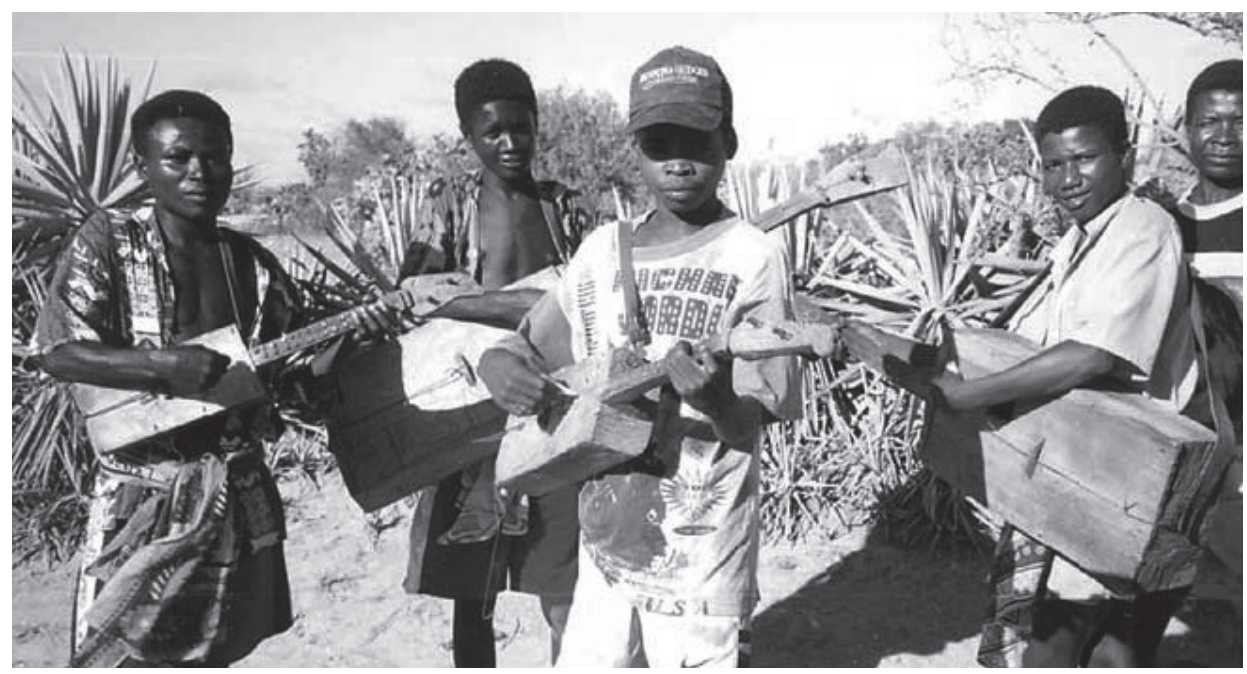

^21. kép Malgasz kabosi lantok Madagaszkár (wikipédia szabad felhasználású oldala nyomán)

A Madagaszkáron elterjedt hosszúnyakú lanttípus a kabosi régi jelenlétére utalhat, hogy a vallási szertartásoktól kezdve, a csalási ünnepségek és a szerenádok, illetve újabban a sporttevékenységek kíséretén át, sokrétü a felhasználási köre. A kabosi lantnak 2 és 6 közötti húrszámú változatai ismertek. A húrokat korábban a szizal pálma rostjaigból sodorták, újabban fémhúrokat tesznek a hangszertípusra. A húrokat zebu szarvból készített plektrummal pengetik. A hangszertest korábban fából vagy teknőspáncélból, újabban olajos dobozból is készülhet. (21. kép) A hangszerelnevezés etimológiai és morfológiai vizsgálata azonban rámutatott, hogy a zanzibári gabbus (gambusi),az ománi gabbus, a comoro-szigeteki gabusi (gambusi) a szaúd-arábiai gabus és a madagaszkári kabosa hangszerelnevezések a belső-ázsiai eredetü rövidnyakú lanttípusig a kobuz-ig vezethetőek vissza (Hilarian 2005:79). Emellett a maláj gambus és a jemeni qambus elnevezések is ide sorolhatóak, illetve egy már bantu elnevezésü rokonhangszer a kibangala (Kaufmann 1990: 318). A belső-ázsiai koboz hangszerteste eredetileg egyetlen fából lett kifaragva, majd a hangerö fokozás igénye miatt, a maláj és az indonéziai egyre hosszabb típusoknál, már megjelenik az illesztett nyak (Collaer 1979:134). (22 kép) Az erede-

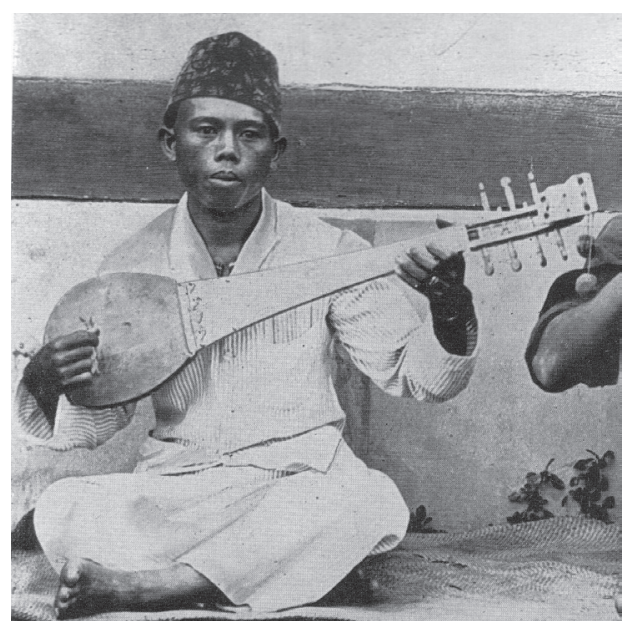

^22. kép Maláj gambus lant Celebesz (Collaer 1979 nyomán) 
tileg rövidnyakú lanttípus az Indiai-óceánon átívelő iszlám migrációval jelenhetett meg Madagaszkáron és a Comore-szigeteken (Sachs 1940: 252). A Comore szigetek Anjuan és Majotte szigetein elterjedt típusnak a hangszertesttel egybefüggő nyaka és egyenes kulcsszekrénye van, amelybe 5 vagy 6 oldalsó állású hangoló kulcs illeszkedik. (23. kép) Ez a kulcsszekrény típus az arab úd rövidnyakú lantokról kerülhetett át a hangszertípusra. A szuahéli partvidék kibangala típusai között szintén elterjedt ez a rövidnyakú lanttípus. Az Indiai-óceán szigetein és Kelet-Afrika partvidékén elterjedt rövidnyakú gabusi lanttípusok a hangszerelnevezések és a morfológiai jellemzői alapján, eredetileg valószínűsíthetően Jemenből és Ománból származnak, de később egyéb hatásokra és a helyi fejlesztések, illetve egyszerüsödések miatt, különböző lokális típusai alakultak ki (Tenaille 2002:270). A későbbiekben azonban egy dobozos hangszertestü gitárformájú, már hosszúnyakú lanttípus is megjelent, és a korábbi rövidnyakú lanttípust kiszorítva, annak elnevezésévé vált a kabosi terminus.

A rövidnyakú lantot ábrázoló legkorábbi ikonográfiai adat az ókori Egyiptomból a XVIII-XX. dinasztiák (Kr.e.1580-1090) idejéből ismert, ahol egy törökülésben ülő zenész játszik plektrummal, egy ovális hangszertestü, hátratört kulcsszekrényü hangszeren (Hickmann 1961:133). (24. kép) Egy későbbi, a XIX-XX. dinasztiák idejéből (Kr.e.1300-1085) származó terrakotta figuránál, már a középkori lantokra jellemző, nagyméretü és ovális hangszertest is megfigyelhető. (25. kép) Bár a szobrocska egy cipusi sírból került elö, a régészek szerint egyiptomi eredetü lehet (Hickmann 1961:134). Mivel az ókori egyiptomi kultúra köréböl a rövidnyakú lantoknak csak ez a két ábrázolása ismert valószínüsíthetö, hogy jövevény hangszerről lehet szó, amely nem tudott szélesebb körben elterjedni (Hickmann-MannicheRashid-Werner 1989:211).

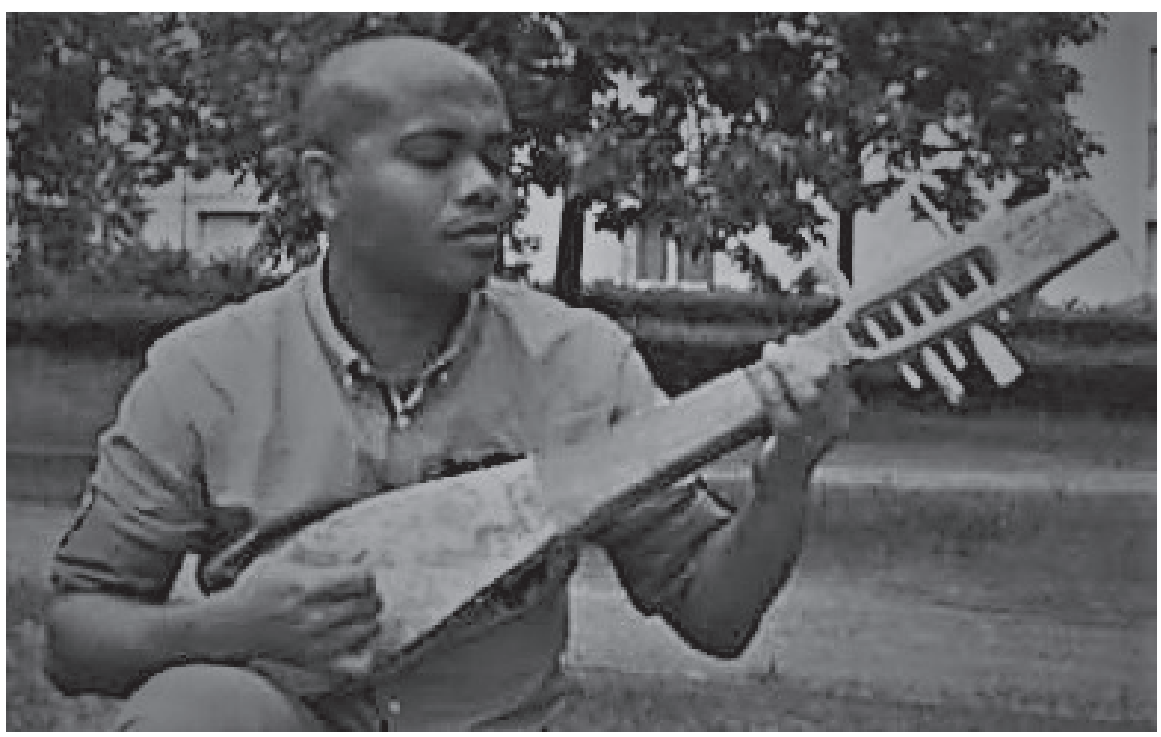

23. kép Szuahéli gambusi lant Comore-szigetek (wikipédia szabadfelhasználású oldalal nyomán) 


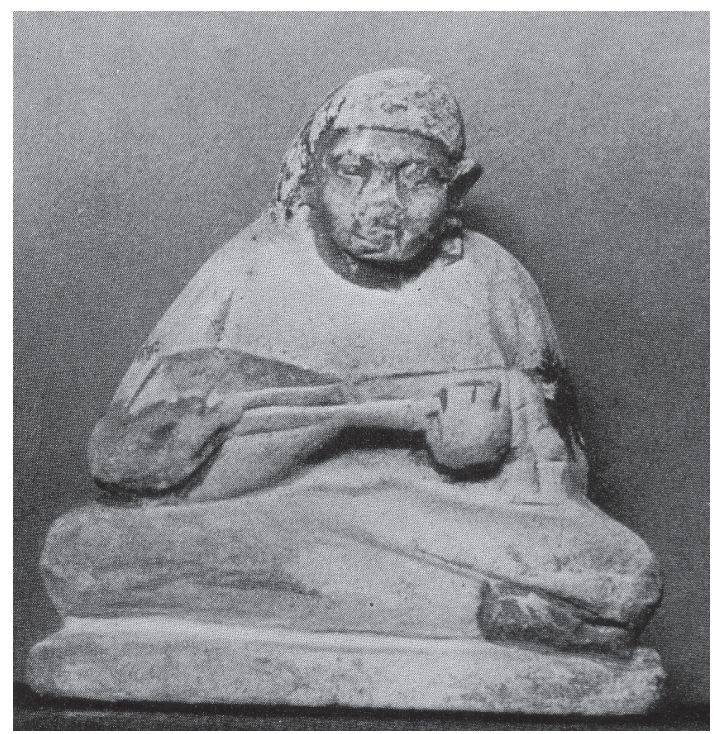

^24. kép Ókori egyiptomi rövidnyakú lant visszahajló kulcsszekrénnyel Kr.e.1580-1090 (Hickmann 1961 nyomán)

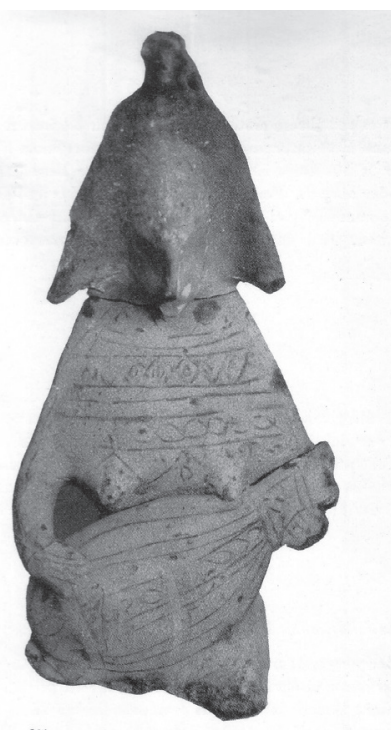

^25. kép Ókori egyiptomi rövidnyakú lant Kr.e.1300-1085 (Hickmann 1961 nyomán)

Az ókori görög ábrázolások esetében hasonló a helyzet, a Kr. e. 300-250 körüli időszakra datálható, Boiótiából előkerült, tanagrai terrakottaszobrocskák között, található egy rövid nyakú, ívelt, palack formájú hangszertestü lanton játszó nőalak. Az ábrázolt rövid nyakú lant hangszerteste, átmenet nélkül vékonyodik hangszernyakká, ami abból adódik, hogy a hangszernyak és a hangszertest ugyanabból az anyagból van kialakítva. Mivel a tanagrai terrakottaplasztikák keletkezésének ideje összefüggésbe hozható Nagy Sándor perzsiai hadjárataival, lehetséges, hogy a rövid nyakú lantok abból a régióból származtak (Mathiesen 1999:284). Ez a lantforma a hellenisztikus befolyásnak köszönhetően a makedón-görög időszakból (Kr. e. 332-330) az egyiptomi Alexandriából szintén adatolható (Hickmann 1961: 134). (26. kép)

A belső-ázsiai rövid nyakú lantok legkorábbi adatai az afrászijábi (mai Szamarkand) szogd kultúrából fennmaradt, a Kr. e. 4-3. századra datált terrakottáiról ismertek, ahol a későbbi kusán korszakból (Kr. e. 1-3. század) származó terrakotta ábrázolásokhoz hasonló nagy, öblös hangszertestü, rövid nyakú lantok láthatók (Karomatov-Meškeris-

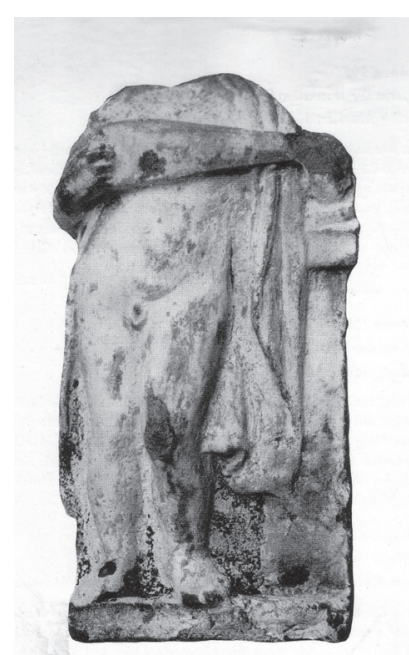

^26. kép Makedón-görög rövidnyakú lant Alexandriából Kr. e. 332-330. (Hickmann 1961 nyomán) 
Vyzgo 1987:74). Az arab úd lanttípus elöképéül szolgáló perzsa barbat rövid nyakú lantot, az észak-baktriai rövid nyakú lantokból eredeztetik (Marcel-Dubois 1942, 205). A közép-ázsiai rövid nyakú lantok őse egy elámi eredetű (Kr. e. 8. század), körte formájú, rövid nyakú lanttípus lehetett, amit a kelet-iráni nyelvủ kusánok terjeszthettek el Belső-Ázsiában és India északi és középső részein (Kaufmannm1981:174). A körte formájú hangszertestü, rövid nyakú lantok I. Sápúr (Kr. u. 241-272) uralkodása idején Afganisztánból és Indiából kerültek át Perzsiába (Farmer 1966:18). Valószínűsíthető, hogy a barbat lanttípus elterjedésével válik szélesebb körben ismertté a hátrahajló kulcsszekrény, amely iráni lanttípus az arab Al-Nadr ibn al-Hárit (624) leírása alapján 590-602 között kezd elterjedni (Farmer 1966:20) Hisam ibn abd al Malik (a szunnita iszlám tizennegyedik kalifája) Omajjád uralkodó palotájának 730-ra datált freskó részletén még egy négyhúros úd látható. (27. kép) Az úd szigorú harmóniai arányok szerint épül fel, és a 9. századból fennmaradt Al-Kindi féle leírása alapján, a test hosszúsága másfélszerese a szélességnek, a szélesség kétszerese a mélységnek, és a nyak hossza pedig negyede a test hosszúságának (Bouterse 1979: 4). Ezek az arányok a hangszertestre vonatkozólag napjainkban is megfigyelhetőek. Más tradíció alapján a húr rezgő hosszúságának, egyenlőnek kell lennie a test hosszúságával. Ennek alapján az újabb hangszereknél azonos korpuszméreteket feltételezve, a nyak meghosszabbodott. A sziciliai Palermo kevert stílusú mủemlékén

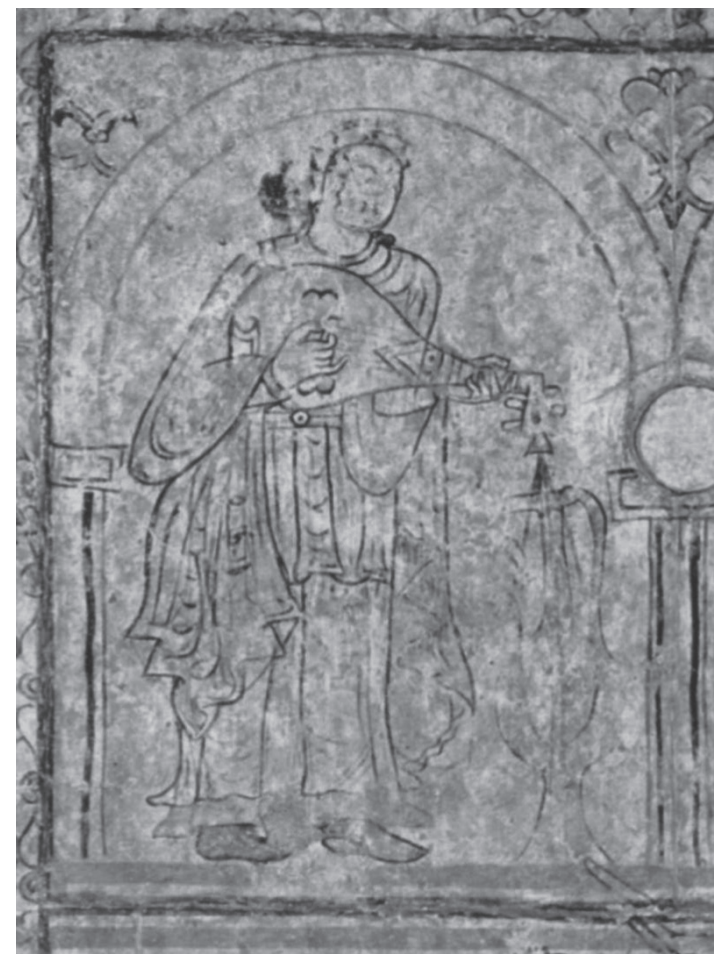

27. kép Sziriai 4 húros úd ábrázolása 737-böl (wikipédia szabad felhasználású oldala nyomán)

Afrika Tanulmányok 
az 1130-40 között épült Capella Palatina kupolájának görög, majd a későbbiekben Fátimida stílusú mozaikdíszítésein, már $4 \times 2$ húrpáros, plektrummal pengetett úd ábrázolások láthatóak. (28. kép) A mai hangszerek húrozata és felépítése kétféle típust mutat, mert amíg a Magreb övezetben elterjedt nyugati úd arbi (andalúz úd) vékonyabb hangszertesttel rendelkezik és $4 \times 2$ húrpárja van. (29. kép) A keleti úd sarqi vagy masri (egyiptomi úd) 5x2 vagy ritkábban $6 \times 2$ húrpáros és több mint két oktáv a hangterjedelme. (30. kép)

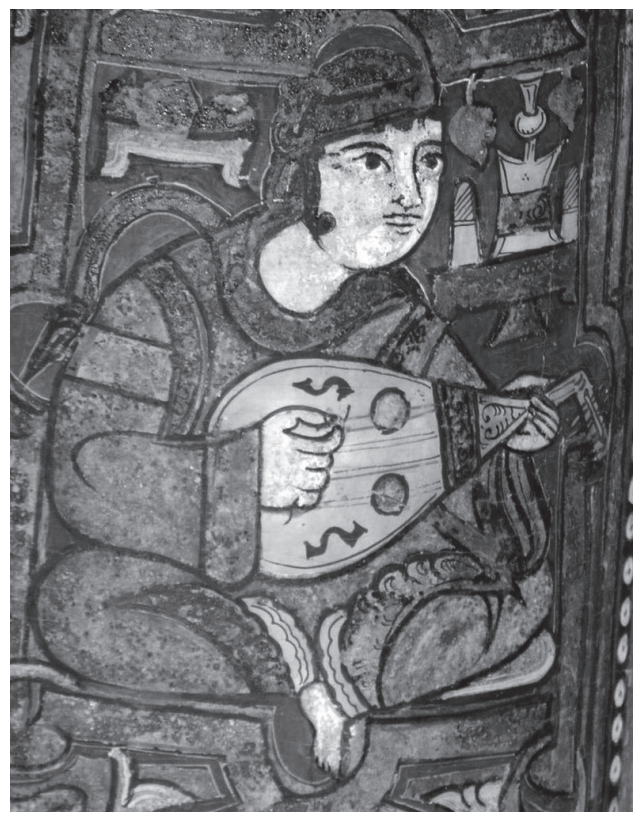

^28. kép 4x2 húros úd ábrázolása 1130-40 Szicilia (wikipédia szabad felhasználású oldala nyomán)

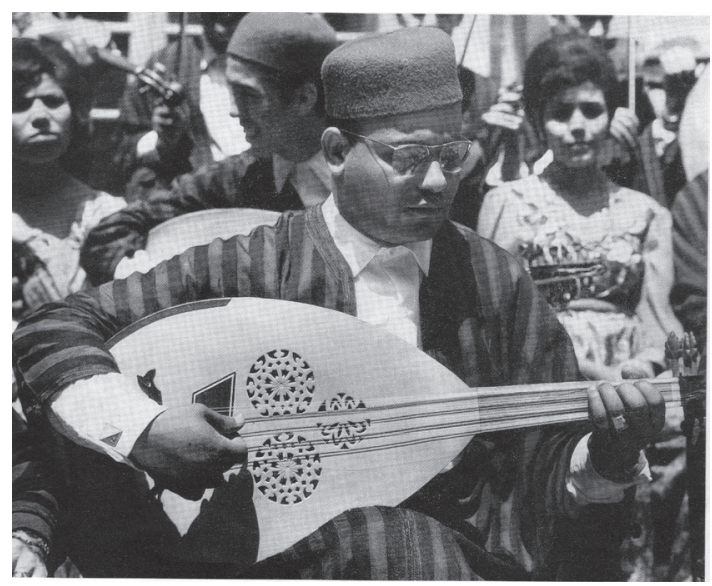

^ 29. kép 4x2 húros úd arbi Tunézia (Collaer-Elsner 1983 nyomán) 


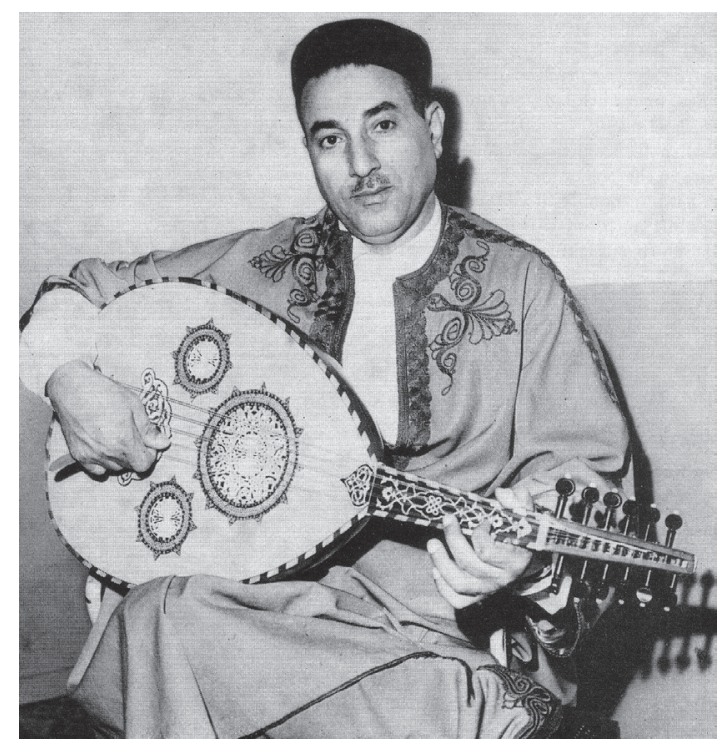

^30. kép 5x2 húros úd sarqi Líbia (Collaer-Elsner 1983 nyomán)

Szintén az úddal rokonítható a Tunéziában, Algériában és Marokkóban is elterjedt kuitra, ami eredetileg négyhúros, majd újabban 4x2 húrpáros kialakítású és felépítésében az údhoz hasonlít, de a hangszertest vékonyabb és a hangszernyak hosszabb kialakítású. A húrok hangolása G-e-A-d, amelyek közül a G húrt a hagyomány által szabályozva egyáltalán nem használják (Collaer-Elsner 1983:108). A G húr elnevezése a rababhoz hasonlóan gawab vagyis 'felelet'. A d húrt lefogás nélkül pengetik, az e-A húrokon játsszák a dallamot. A kuitra elnevezését a kithara és a gitár terminusokkal lehet összefüggésbe hozni (Sendrey 1974:178). Sem az úd sem a kuitra lanttípusok nem terjedtek el a szubszharai Afrika térségében.

Összességében a történeti áttekintés rámutat arra tényre, hogy a lanttípusú hangszerek is jövevények az afrikai kontinensen, azonban az észak-afrikai régióban még így is több évezredes hagyománnyal lehet számolni, mert a hangszertípus első megjelenése az ókori Egyiptomból már a XVIII. dinasztia időszakából (Kr.e.1550-1292) adatolható. A hosszúnyakú lantok a berber népcsoportok használatában maradhattak fenn, és széleskörü nyugat-afrikai elterjedésük csak a 14. századtól datálható amikor az iszlám vallás elterjedésével a vadász/pap csoportokból kialakuló zenész/ énekes kaszt a korábbi, korlátozott hang képzésére alkalmas néhány húros íjhárfáit lecserélte a berberektől átvett, hangológyürüs húrfeszítési módja miatt fejlettebb típusnak számító hosszúnyakú lantokkal. Ezt a paradigamváltást jeleníti meg a „Gasszire lantja’ epikus énekciklus. De ezzel párhuzamosan a lantok és az ijhárfák kereszteződéséből a hárfalantok is kialakultak, így azok nagyobb hangszertestű és sokhúros típusai vetélytársaivá válhattak az arab törzsekkel elterjedő városi hangszernek, a rövidnyakú úd lanttípusnak. Ami valószínủleg ennek köszönhetően nem terjedt el a nyugat-afrikai iszlamizált népcsoportok körében, viszont a 13. században 
spanyol átvétellel Európában népszerủ hangszerré vált. A hosszúnyakú lantok kizárólagos észak- és nyugat-afrikai elterjedése egyben azt is igazolja, hogy a hárfákkal és a lírákkal ellentétben a hosszúnyakú lantokat nem vették át a nílusi nyelvủ népek. Ellenkező esetben a nílusi nyelvủ népcsoportok déli irányú vándorlásával a hosszúnyakú lantok is elterjedtek volna a közép- és a kelet-afrikai régióban. Ugyanezen okból az is feltételezhető, hogy csak a bantu expanzió utáni időszakban jelenhettek meg a nyugat-afrikai régióban és azt megelőzően mintegy 3 ezer éven át kizárólag a berber népcsoport körében maradhatott fenn a használatuk. A vélhetően BelsöÁzsiában kialakuló, de legalább is onnan elterjedő rövidnyakú lantok archaikusabb, egyetlen fából kifaragott palackformájú típusa szintén az iszlám terjeszkedéssel terjedhetett el Délkelet-Ázsiában, majd jelenhetett meg az Indiai óceán szigetvilágában, és nyomokban Kelet-Afrikában is. Szélesebb körủ elterjedésének valószínüleg a régióban elterjedt konkurrens hangszerek a hárfák és a lírák szabhattak gátat. Ezen túlmenően a hangerő fokozásának általános igényeként, az egyetlen fából faragott rövidnyakú lantokat, felépítésüknek köszönhetően nem lehetett tovább fejleszteni, ezért terjedhettek el az utóbbi időben a nagyobb, dobozos hangszertesttel rendelkező hosszúnyakú lanttípusok a kelet- és a dél-afrikai régiók lakosai körében.

\section{Jegyzetek}

1 Tekintve, hogy nagyon sok afrikai hangszer és népcsoport elnevezésnek nincs magyar megfelelöje, az afrikai hangszerelnevezéseknél a The New Grove Dictionary of Musical Instruments terminusai, és az afrikai népcsoportok elnevezéseinél a The Peoples of Africa. An Ethnohistorical Dictionary az irányadó. Kivételt képeznek az olyan elnevezések amelyek magyar megfelelői régóta használatban vannak, ezért az angol forma felesleges és félreérthető lenne.

2 NMAGy ltsz: 26081

3 NMAGy ltsz: 26082

4 NMAGy ltsz: 66.102 .3

5 NMAGy ltsz: 124945

6 NMAGy ltsz: 3795

7 Wagadu az ősi Ghána állam elnevezése volt és nem összetévesztendő a mai Burkina Faso fövárosával Ouagadougou (Vagadogu)-val. Illetve a középkori Ghána állam, ahonnan az akan népek ősei erednek, sem a mai Ghánai Köztársaság területén, hanem attól északabbra, a mai Mauritánia Mali és Szenegál területén feküdt.

8 A soninke és a marka népcsoport körében a dauszi vagyis a hősök könyve a különböző epikus novellák gyüjteménye (Frobenius 1981: 272)

9 A baobab fába temetkezésről már Frobenius is beszámol, azonban hangsúlyozza, hogy ez inkább adott népcsoport jellemzője és nem csak a griotokat temették oda (Fobenius 1921: 42).

10 NMAGy ltsz. 68.4.1.

11 https://hu.wikipedia.org/wiki/Bendzsó 


\section{Felhasznált irodalom}

- AMES, Dawid W (1973): „A Sociocultural View of Hausa Musical Activity,” in The Traditional Artist in African Societies, ed. Warren L. D'Azevedo, Bloomington: Indiana University

- APPIAH, Kwame Anthony-GATES, Henry Louis szerk. (2010): Encyclopedia of Africa. Oxford University Press

- BARABÁS Jenő (1963): Kartográfiai módszer a néprajzban. Budapest: Akadémiai Kiadó

- Ibn BATUTTA, Rihla (1981): In: LEVTZION, Nehemia-HOPKINS, J. F. P. (translated \& edited) Corpus of Early Arabic Sources for West African History. pp. 279-304, Cambridge: Cambridge University Press

- BIRD, Charles S (1972): Heroic Songs of the Mande Hunters. In: DORSON, Richard (szerk) African Folklore. Bloomington 275-93, 441-77.

- BOUTERSE, Curtis (1979): Reconstructing the Medieval Arabic Lute: A Reconsideration of Farmer's ,Structure of the Arabic and Persian Lute' The Galpin Society Journal, Vol. 32 (May), pp. 2-9

- BRAUER-BENKE, József (2007): Afrikai hangszerek. Budapest: L’Harmattan

- BRAUER-BENKE, József (2009): A hárfalant. Egy nyugat-afrikai hangszer története. Afrika Tanulmányok 3: 3-4. 104-109.

- BRAUER-BENKE, József (2015): Az afrikai líra hangszertípus történeti áttekintése. Afrika Tanulmányok 9: 1, 37-53.

- BRAUER-BENKE, József (2018): Egy eredeti afrikai hangszertípus, a lamellofonok jellemzői és történeti áttekintése. Afrika Tanulmányok 11: 3/4, 53-69.

- CHARRY, Eric S (1996): Plucked Lutes in West-Africa: an Historical Owerwiew The Galpin Society Journal, Leicester 49. Mar. 3-37.

- CHARRY, Eric S (2000): Mande Music: Traditional and Modern Music of the Maninka and Mandinka of Western Africa. University of Chicago Press

- COLlAER, Paul szerk. (1979): Südostasien. Musikgeschichtein Bildern, Deutscher Verlag für Musik Band.1.Lfg.3. Leipzig

- COLlAER, Paul-ELSNER, Jürgen szerk. (1983): Nordafrika. Musikgeschichtein Bildern, Deutscher Verlag für Musik Bd.1.Lfg. 9. Leipzig

- CONRAD, David C.-FRANK, Barbara E. eds. (1995): Status and Identity in West Africa: Nyamakalaw of Mande. Bloomington:Indiana University Press.

- COOLEN, Michael T. (1983): The Wolof Xalam Tradition of the Senegambia. Ethnomusicology, Vol. 27, No. 3 (Sep.), pp. 477-498.

- ERLMANN, Veit (1986): Music and the Islamic Reform in the Early Sokoto Empire. Stuttgart: Steiner Verlag Wiesbaden GmbH

- FARMER, Henry George (1924): The Arab Influence on Music in the Western Soudan,

- Musical Standard 24/448, 158-9.

- FARMER, Henry George (1938): „Tunbúr”, In: The Encyclopaedia of Islam, supplement, ed.

- Houtsma, Wensinck, Gibb, Heffening, and Levi-Provenqal Leiden: E.J. Brill, 251-3.

- FARMER, Henry George (1966): Islam. Musikgeschichtein Bildern, Bd.3.Lfg.2. Leipzig: Deutscher Verlag für Musik

- FROBENIUS, Leo (1921): Speilmanns-Geschichten der Sahel, Atlantis, Bd. VI. Jena: E. Diderichs Verlag

- FROBENIUS, Leo-FOX, Douglas Claughton (1938): African Genesis.London : Faber \& Faber Ltd.

- FROBENIUS, Leo (1981): Afrikai kultúrák. Fordította: G. Beke Margit, Kárpáty Csilla, Soltész Gáspár, Budapest: Gondolat

- GERTEINY, Alfred G (1967): Mauritania. London: PalI Mall Press

- HALE, Thomas A (1997): From the Griot of Roots to the Roots of Griot: A New Look at the Origins of a Controversial African Term for Bard. Oral Tradition, 12/2: 249-278 
- HARTONG, Jan Laurens (2006): Musical terms worldwide: a companion for the musical explorer. Hague: Semar

- HAUSE, Helen Engel (1948): Terms for Musical Instruments in the Sudanic Languages. University of Pennsylvania

- HICKMANN, Hans (1961): Ägypten. Musikgeschichtein Bildern, Deutscher Verlag für Musik Bd.2.Lfg.1.Leipzig

- HICKMANN, Ellen - MANNICHE, Lise - RASHID, Subhi Anwar - WERNER, Eric 1989:

- Die Musik des Altertums. Neues Handbuch der Musikwissenschaft I. (szerk. RIETMÜLLER, Albrecht - ZAMINER, Frieder). Wiesbaden: Laaber

- HILARIAN, Larry Francis (2005): The Structure and Development of the Gambus (MalayLutes) The Galpin Society Journal, vol. 58 (May), pp. 66-82, 215-216.

- JABLOW, Alta (1984): Gassire's Lute: A Reconstruction of Soninke Bardic Art. Research in African Literatures, Vol. 15, No. 4, Special Issue on Oral Poetry andSong (Winter), pp. 519529. Indiana University Press

- JÄGFORS, Ulf (2003): The African Akonting and the Origin of the Banjo. The Old-Time Herald, 9/2, 26-33.

- JANKOWSKY, Richard C (2010): Stambeli: Music, Trance, and Alterity in Tunisia. Chicago: University of Chicago Press

- KAUFMANN, Walter (1990): Selected musical terms of non-Western cultures:a notebookglossary. Harmonie Park Press

- KIRBY, Percival Robson (1968): The Musical Instruments Of the Native Racis of South Africa. Johannesburg: Witwatersand University Press

- KUBIK, Gerhard szerk. (1989) Westafrika. Musikgeschichtein Bildern, Deutscher Verlag für Musik. Bd.1.Lfg.11.Leipzig

- Sieur le MAIRE, Jacob (1965): Voyages du Sieur le Maire aux les Canaries, Cap-Verd, Sénégal et Gambie. Paris: Chez Jacques Collombat

- MARCEL-DUBOIS, Claudie (1942): Les instruments de musique de l'Inde ancienne. Paris:

- Presses universitaires de France

- MARCUSE, Sibyl (1975): Survey of Musical Instruments. London: HarperCollins Publishers

- MARKÓ Miklós: Cigányzenészek albuma. Budapest: Magánkiadás

- MATHIESEN, Thomas J. (1999): Apollo's Lyre. Greek Music and music theory in antiquity

- and the Middle Ages. Lincoln-London: University of Nebraska Press

- MENTZEL, Otto Friedrich (1787): Beschreibung des Vorgebirges der Guten Hoffnung. Glogau: Günther

- NOOSHIN, Laudan (2009): Music and the play of power in the Middle East, North Africa and Central Asia. Farnham:Ashgate Publising Limited

- RASHID, Subhi Anwar (1984): Mesopotamien. Musikgeschichtein Bildern, Deutscher Verlag für Musik. Bd.2.Lfg.2.Lepizig

- SACHS, Curt (1940): The History of Musical Instruments. New York-London: Norton \& Company,

- SCHAFFER, Matt (2005): Bound to Africa: The Mandinka Legacy in the New World. History in Africa, 2005, Vol. 32., pp. 321-369.

- SENDREY, Alfred (1974): Music in the social and religious life of antiquity. Fairleigh Dickinson University Press

- SZOLNOKY Lajos (1954): Próbalapok korszerübb néprajzi kartográfiához. Néprajzi Értesítő, Budapest 36. 65-66.

- SZOMBATHY Zoltán (2021): Az iszlám Fekete-Afrikában. Piliscsaba: Avicenna Közel-Kelet Kutatások Intézete

- TANG, Patricia (2007): Master of the sabar: Wolof griot percussionist of Senegal. Philadelphia 
- al-UMARÍ, Ibn Fadl Alláh (1981): Masálik al absár fi mamálik al amsár. In: LEVTZION, Nehemia-HOPKINS, J. F. P. (translated \& edited) Corpus of Early Arabic Sources for West African History. pp. 252-278, Cambridge: Cambridge University Press

- WEEKES, Richard V. szerk. (1984): Muslim Peoples: A World Ethnographic Survey. Second Edition, Revised and Expanded. Westport (CT): Greenwood Press. 1 kötet.

A szerzőről

PhD, tudományos

fömunkatárs

Bölcsészettudományi

Kutatóközpont,

Zenetudományi Intézet

About the Author

PhD, Senior Research

Fellow

Research Centre for the

Humanities

Institute for Musicology

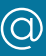

braverbenke@hotmail.com

\section{English Abstract}

\section{The African Lute}

The historical survey presented here demonstrates that musical instruments of the lute type derive from outside the African continent, even though they have probably been present in the North African region for several millennia. The first evidence of their appearance in ancient Egypt goes back to the era of Dynasty XVIII (ca. 1550-1292 BCE). The use of lutes having a long neck may have been preserved later among various Berber-speaking populations, and their wide dissemination over West Africa can only be dated with certainty to the period after the 14th century, when widespread conversion to Islam led to the replacement of an older arched type (having few strings and capable of producing a limited range of sounds) with a long-necked lute type borrowed from the Berbers, which can be considered more advanced owing to its mode of stretching the strings with a tuning ring. This paradigm shift is obvious in the epic song cycle known as Gassire's Lute. Parallel to this development harp lutes appeared as a kind of cross between lutes and bow harps; and types of this new instrument having a larger body and multiple strings could rival the short-necked oud, an urban instrument spread by Arab tribes. Perhaps for this reason, the latter was not widely adopted among the Islamized populations of West Africa, while it did become popular in Europe in the 13th century, first adopted by the Spaniards. The fact that long-necked lutes are found only in North and West Africa also proves that the Nilotic-speaking peoples did not borrow these, unlike harps and lyras, which they did. Had they done so, the southward expansion of Nilotic-speaking populations would have led to the distribution of long-necked lutes over Central and Eastern Africa. For the same reason these instruments must have appeared in West Africa only after the Bantu expansion, before which era their use must have been restricted to Berber-speaking groups for three millennia. Short-necked lutes are likely to have been originated in Central Asia and they certainly spread from that region; the archaic type that is carved from one block of wood and has a bottle-like shape spread to Southeast Asia with the Muslim expansion and may have been carried from there to the islands of the Indian Ocean and sporadically to East Africa as well. Its wider adoption over the latter region was probably hindered by the ubiquity of rival instruments (harps and lyras) there. Moreover, the short-necked lutes carved of a single block of wood were not suitable for further development with the aim of increasing the volume, hence the recent widespread adoption among the inhabitants of the eastern and southern regions of Africa of a long-necked lute type having a larger, box-like body. 